\title{
The melliferous flora of Veracruz, Mexico
}

\author{
Real-Luna, Natalia ${ }^{1,2}$; Rivera-Hernández, Jaime E. ${ }^{3}$; Alcántara-Salinas, Graciela; \\ Zalazar-Marcial, Edgardo'; Pérez-Sato, Juan A. ${ }^{{ }^{*}}$
}

${ }^{1}$ Colegio de Postgraduados Campus Córdoba. Carretera Federal Córdoba-Veracruz km 348 , Manuel León, Amatlán de los Reyes, Veracruz, México. C. P. 94953. ²Doctorado en Ciencias Naturales para el Desarrollo (DOCINADE) Instituto Tecnológico de Costa Rica, Universidad Nacional, Universidad Estatal a Distancia, Costa Rica. ${ }^{3}$ Centro de Estudios Geográficos, Biológicos y Comunitarios, S.C. Córdoba, Veracruz, México. C. P. 94500.

*Corresponding author: pantonio (acolpos.mx

\begin{abstract}
Objective: To contribute to the knowledge of the situation of the melliferous flora in Veracruz for pollinators and to communicate it for the benefit of beekeepers and stingless beekeepers, as well as to develop comprehensive strategies with these activities

Design/Methodology/Approach: The information was obtained through a bibliographic review in reference databases such as Scopus, Web of Science Group, Academic Google, Elsevier and Springer Link, using the following keywords: flora, bees, pollinators, honey, pollen.

Results: 63 families were recorded, with 176 genera and 216 species of melliferous flora, finding that the largest number of species are found in the Fabaceae family (20\%) and Asteraceae (16.55\%). There were also 44 crops with 22 families.

Study Limitations/Implications: There were no limitations in conducting this study.

Findings/Conclusions: The greatest diversity of melliferous flora species is related to wild plants, and strategies need to be implemented for their protection and multiplication. For these actions, various actors must be involved at different levels of government, educational and private institutions, civil society, farmers, beekeepers, and stingless beekeeping Conservation actions include the use of melliferous plants in gardens and their protection in crops, sites surrounding crops and on edges. It is necessary to preserve natural landscapes and restore damaged ones, as well as to lead favorable practices in pollinator-dependent crops.
\end{abstract}

Keywords: flora, bees, pollinators, honey, pollen.

\section{INTRODUCTION}

BeS maintain a close relationship with melliferous flora, since they depend on them for their food, when Bees consuming nectar and pollen obteined from the flowers. Likewise, they also collect resinous material that they use for the construction of their nest and for the elaboration of propolis, which serve as protection against pathogens and predators (Bonet and Vergara, 2016). 
Melliferous flora or honey flora is made up of plants that produce resins or whose flowers produce nectar and/ or pollen; it is classified into polliniferous, nectariferous or pollen-nectariferous (Montoya-Bonilla et al., 2017). In exchange for food or resins that the bees receive from wild and cultivated plants, they pollinize their flowers thus favoring the formation of fruits that serve as food for human beings and other animals, contributing with this to food security and ecological equilibrium of ecosystems (Alquisira-Ramírez, 2019).

The availability of flower resources for the development and reproduction of bee colonies is required during the whole year. This is achieved through short flowering periods that most agricultural crops have, as well as native plants of the Asteraceae and Fabaceae families, which are important to feed the populations of bees and other pollinators because they are the most visited (González-Suárez et al., 2020).

The conservation and multiplication of melliferous flora is of huge interest for beekeepers and meliponiculture producers, because they ensure the production and quality of honey from their bee colonies (AraujoMondragón and Redonda-Martínez, 2019). In order to achieve this, the following strategies have been applied: use of melliferous plants in agroecologic gardens, or else interspersed in the crops or on the edges of the paths (Kremen and M'Gonigle, 2015; Landaverde-González et al., 2017)

The implementation of conservation strategies for both melliferous flora and pollinators is vital, since the absence or decline of the populations of any of them can impact their survival, in addition to reducing the production of fruits and seeds, which will have an environmental, social and economic impact globally (Hipólito et al., 2016; Wilson et al., 2017).

Therefore, the objective of this study was to understand the situation of the melliferous flora of the state of Veracruz, Mexico, through a bibliographic review with the aim of broadening knowledge about the available flower resources for pollinators, in addition to contributing with this information to beekeepers and meliponiculture producers to develop integral strategies in these activities.

\section{MATERIALS AND METHODS}

The information of melliferous flora of the state of Veracruz, Mexico, was obtained through the bibliographic review of the reference databases Scopus, Web of Science Group, Academic Google, Elsevier and Springer Link, using the following keywords: flora, bees, pollinators, honey, pollen. The information was systematized assigning categories of use, phenology, taxonomy and biology, in the following way: family, scientific name, resource that bees are supplied with - nectar or pollen-, flowering period, status - whether native, exotic or naturalized-, and life form; in the case of crops pollinated by bees, the common name was added.

\section{RESULTS AND DISCUSSION Flora in Mexico}

In Mexico there is a record of 23,314 species of vascular plants, among which 2,854 genera, 297 families and 73 orders were included; in this flora there are 149 gymnosperms and 22,126 angiosperms (Ulloa et al., 2017; Villaseñor, 2016). The state of Veracruz occupies the third place in floristic richness of the country (Martínez-Adriano et al., 2016), divided into 271 families, 1,956 genera and 8,497 species (Villaseñor, 2016).

Despite the great floristic richness of Veracruz, it is primarily threatened by deforestation, as shown in a study carried out by Von et al. (2021), in three regions of the state of Veracruz from 2003 to 2013, in the region of the Tuxtlas, with a loss of natural plant coverage of $4.6 \%$ (3,516 ha), the old Antigua with 2\% (1,634 ha) and Sierra de Otontepec with 1.4\% (618 ha). This deforestation also causes fragmentation of habitats, loss of soil fertility, loss of biodiversity, and reduction of environmental services (Ramírez-Bravo and Hernández-Santin, 2016).

Additionally, erosion and genetic loss were caused by the loss of biodiversity, since angiosperms present reduced germination and progeny of lower quality (Aguilar et al., 2019), because of the loss of biological corridors for their pollinators (Gómez-Pompa et al., 2010), which has the consequence of smaller, scarce and isolated populations at the local scale, landscape and regional, with which their probability of extinction increases (Auffret et al., 2017)

\section{Bee-Plant Ecological Interactions}

Bees have evolved with plants and present a complex network of inter-specific interactions where sight, smell, moisture detection, contact and weak electrostatic field between a flower and a bee are involved; through these 
interactions flowers use bees as vehicles for the transport of pollen for fertilization (Thakur and Nanda, 2020), and the bees benefit from nectar and pollen as sources of food that plants provide, thus establishing an ecological relationship between them known as mutualism. Therefore, bees are attracted by the nectar which is an aqueous substance, rich in sugars, which contributes carbohydrates as main source of energy for the bees. During nectar collection, bees transport pollen from the anthers to the stigma of the plants, thus benefiting a large number of species of angiosperms (CastellanosPotenciano et al., 2012).

Bees, in addition to nectar, use the pollen that they find in the anthers (apical part) of the stamens, both in angiosperms and in gymnosperms; during their visits, foraging bees attract these grains of pollen through the generation of a weak electrostatic field generated between the flower (with negative charge) and the bee's body (positive charge) (Clarke et al., 2017).

The way in which the bees harvest pollen from the flowers is by scraping or licking the anther and then sticking it on the carbuncle (cavity that is found in the tibia of the third pair of legs), using nectar to stick the pollen and thus transport it, accumulating it in form of granules; then, they take it to their nest and, generally, they deposit it around the breeding area where the larvae are developing, since it is the protein source for larvae and adults, containing between 10 and $40 \%$ of protein (Leonhardt et al., 2007; Vossler, 2015).

Pollen is an indicator that allows understanding the botanical and geographic characteristics of beekeeping products such as honey (Stephen, 2014; Thakur and Nanda, 2020). In addition, bees collect resins from some plants for the production of propolis, which they use as building material and defensive substance (Bankova et al., 2018).

The interactions that happen between plant and pollinator play an important role in the structure of communities, in addition to determining the diversity, wealth and persistence of species in a specific locality (Martínez-Adriano et al., 2018). Entomopalynology studies pollen found in the body or in the intestine of insects and provides information about the migration routes and their feeding, in addition to defining the pollination mechanisms and the foraging resources. Another important research area is Melissopalynology, which studies the botanical and geographic origin of honey, through the analysis of pollen in honey (Stephen, 2014). In palynological studies, there are records that bees, particularly Apis mellifera, visit approximately 2,000 plant species (Cadena et al., 2019).

\section{Melliferous Plant Species in Veracruz, Mexico}

Based on the information gathered through scientific search engines, an inventory of 63 families were obtained, with 176 genera and 216 species of melliferous flora in the state of Veracruz, Mexico. The families that present the highest number of genera are Fabaceae with $20 \%$, and Asteraceae with $16.55 \%$, the same as the highest number of species (Fabaceae $22.58 \%$ and Asteraceae 15.59\%) (Table 1, Annex 1), as mentioned by GonzálezSuárez et al. (2020).

Most of the species of melliferous flora reported for the state of Veracruz are native (85.65\%), exotic species contribute $10.19 \%$ and naturalized $4.17 \%$. Concerning their life form, $37.04 \%$ are trees, $33.80 \%$ are herbaceous, $24.07 \%$ shrubs, $2.31 \%$ arborescent, $2.31 \%$ vines, and $0.46 \%$ liana. Most of the species of melliferous flora are nectar-producing (37.96\%), followed by pollenproducing (32.87\%) and, in lower numbers, there are pollen-nectariferous (29.17\%) (Figure 1).

The Asteraceae family is one of the most diverse plant families in Mexico, with around 392 genera and approximately 3,005 species; several of its species are of interest to beekeepers (Cadena et al., 2019), so they are considered as a nectar-polliniferous family. The

Table 1. The most representative melliferous flora families of
Veracruz, Mexico.
\begin{tabular}{l|c|c|c|c}
\hline Family & Genus & $\%$ & Species & $\%$ \\
\hline Asteraceae & 24 & 16.55 & 29 & 15.59 \\
\hline Combretaceae & 4 & 2.76 & 4 & 2.15 \\
\hline Commelinaceae & 4 & 2.76 & 4 & 2.15 \\
\hline Convolvulaceae & 3 & 2.07 & 6 & 3.23 \\
\hline Euphorbiaceae & 6 & 4.14 & 7 & 3.76 \\
\hline Fabaceae & 29 & 20 & 42 & 22.58 \\
\hline Lamiaceae & 6 & 4.14 & 9 & 4.84 \\
\hline Malvaceae & 8 & 5.52 & 10 & 5.38 \\
\hline Myrtaceae & 4 & 2.76 & 5 & 2.69 \\
\hline Poaceae & 4 & 2.76 & 5 & 2.69 \\
\hline Rubiaceae & 4 & 2.76 & 4 & 2.15 \\
\hline Sapindaceae & 7 & 4.83 & 8 & 4.30 \\
\hline Verbenaceae & 4 & 2.76 & 4 & 2.15 \\
\hline & & & &
\end{tabular}




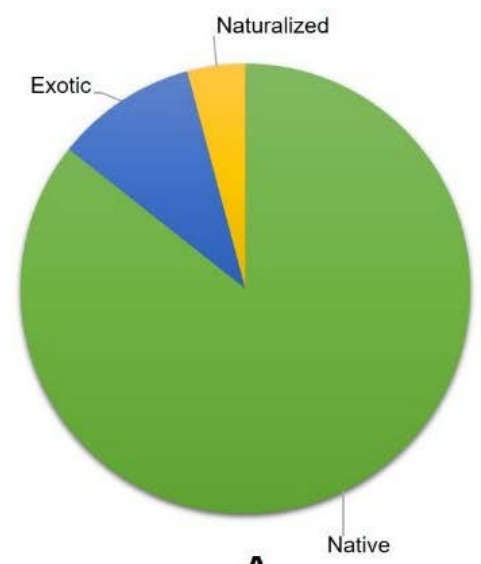

A

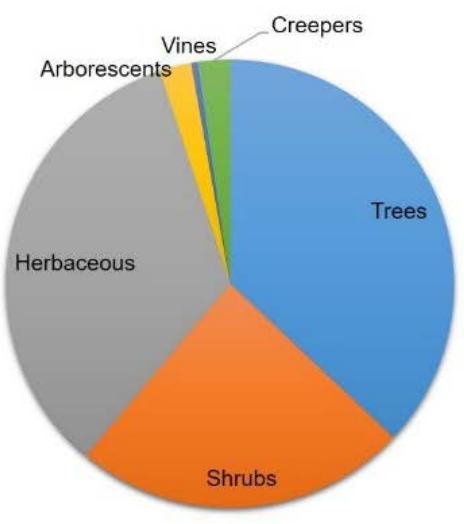

B

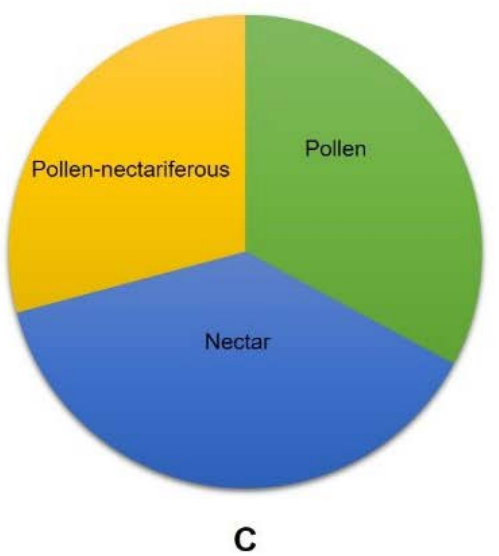

C

Figure 1. Main characteristics of melliferous flora: A) Status, B) Life form and C) Resource offered to pollinators.

Fabaceae family is also one of the most important in Mexico, since it presents 139 genera and 1,850 species (Ramírez-Arriaga et al., 2016).

On the other hand, there is a record of 44 plant species that are cultivated and visited by bees to obtain their food; these crops belong to 23 botanical families, of which $43.18 \%$ are nectariferous and the same percentage are also pollen-nectariferous, and only $9.09 \%$ are polliniferous (Annex 2, Figure 2).

The crops that depend on pollination are soybean, coffee, tomato and orange; the importance of pollinators in agricultural crops is that they improve the yield and quality of the seeds and fruits, so this service presents a social and economic impact (Giannini et al., 2020); however, some of the crops only provide food to pollinators during a few weeks, that is, during a short period, and then they must survive a long scarcity, and although some may migrate, social pollinators require accessible floral resources throughout the year for survival of the colony. For that, wild melliferous flora can provide food and nesting sites, so changes must be made in agricultural practices to foster biodiversity and restore, at least to a certain degree, the complexity of the ecosystem, as well as its functionality and sustainability (Kevan and Silva, 2020).

On the other hand, regional and local crops could depend on more
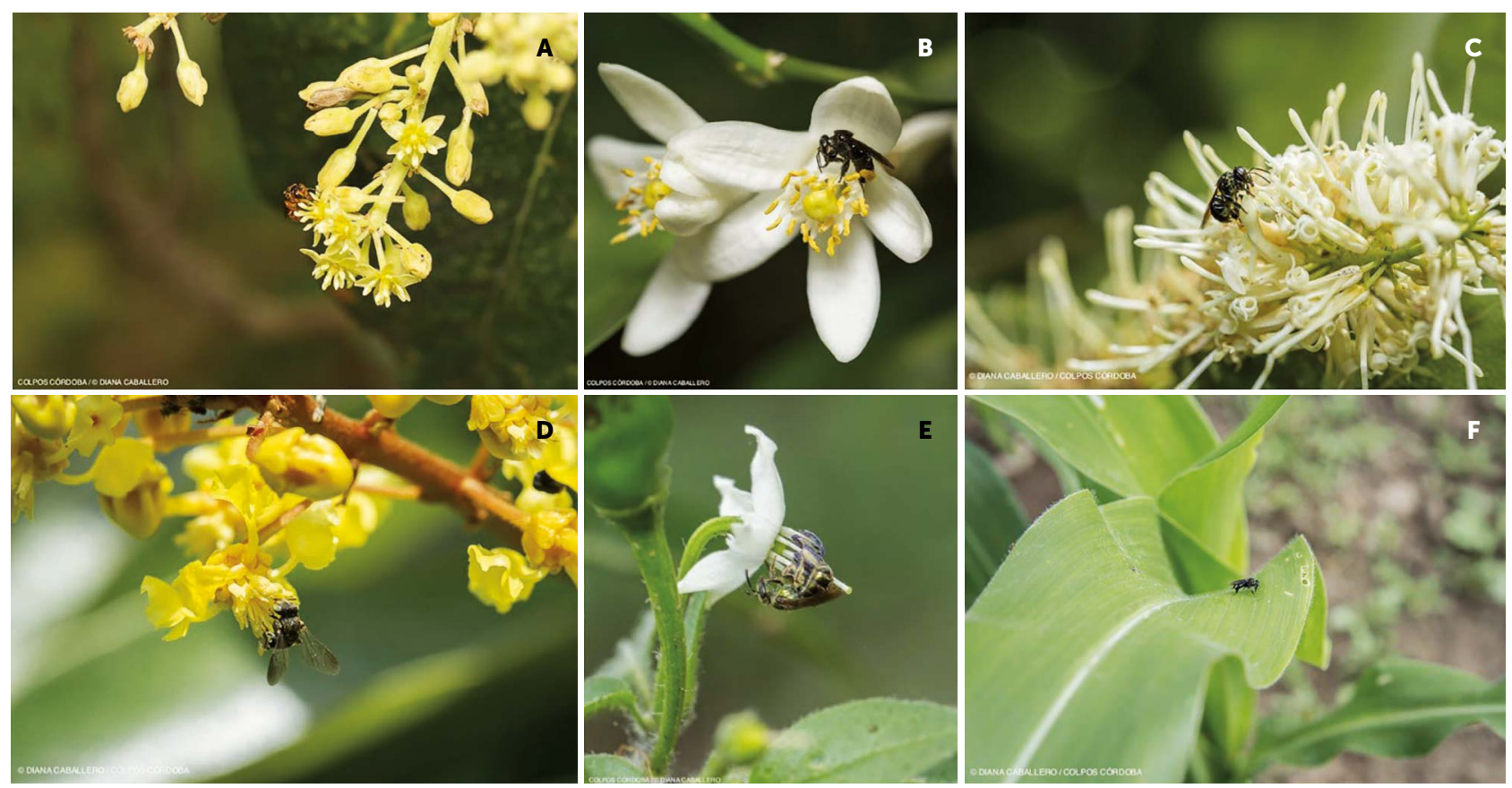

Figure 2. Crops pollinated by bees: A) Persea americana Mill., B) Citrus limon (L.) Osbeck, C) Macadamia integrifolia Maiden \& Betche D) Byrsonima crassifolia (L.) Kunth, E) Capsicum annuum L. y F) Zea mays L. Photographs: Diana Caballero Alvarado. 
specialized pollinators, although more research in this regard is required, particularly in small-scale agriculture, since this benefits the local and regional economy, in addition to this knowledge being important in local communities (Giannini et al., 2020).

Beekeeping and meliponiculture are important activities thanks to the pollination service that they provide, in addition to the products that bees provide to human beings, such as honey, pollen, wax and propolis, which arise directly or indirectly from the melliferous flora from which working bees feed (Kevan and Silva, 2020).

\section{CONCLUSIONS}

In Veracruz there is a great richness of melliferous flora represented by 215 wild plant species, the vast majority of species belong to Fabaceae (20\%) and Asteraceae (16.55\%). There were also 44 crops detected that provide pollen and nectar to the bees.

The bibliographic references analyzed in this study report that melliferous flora is represented essentially by wild plants, which tend to be eliminated because they are considered weeds. Due to the importance of this type of plants in the life of bees, it is necessary to implement strategies for their protection and reproduction. These actions involve various actors at different levels of government, educational and private institutions, as well as in civil society, although especially farmers, beekeepers and meliponiculture producers. Among the actions for conservation of melliferous flora, the use of melliferous plants in garden design stands out, both in urban and in rural zones in places next to the crops or edges, whether of crops, paths, forests, etc. It is necessary to conserve natural landscapes and restore those damaged by agriculture and livestock activities, as well as using favorable practices for bees in agriculture, primarily for the crops on which these pollinators depend.

\section{REFERENCES}

Aguilar, R., Cristóbal-Pérez, E. J., Balvino-Olvera, F. J., De Jesús AguilarAguilar, M., Aguirre-Acosta, N., Ashworth, L., Lobo, J. A., MarténRodríguez, S., Fuchs, E. J., Sanchez-Montoya, G., Bernardello G., y Quesada, M. (2019). Habitat fragmentation reduces plant progeny quality: a global synthesis. Ecology Letters, 22(7). 1163-1173. https://doi.org/10.1111/ele.13272

Alquisira-Ramírez, E. V. (2019). La importancia de la meliponicultura en México. Retos y oportunidades. Parte 2. Los saberes y conocimientos como parte de la seguridad alimentaria. In E. Román-Montes de Oca (Ed.), Prácticas agropecuarias como estrategias de seguridad alimentaria (pp. 103-129). http:// investigacion.uaem.mx/archivos/epub/practicas-agropecuariasseguridad/practicas-agropecuarias-seguridad.pdf

Araujo-Mondragón, F., y Redonda-Martínez, R. (2019). Flora melífera de la región centro-este del municipio de Pátzcuaro, Michoacán, México. Acta Botanica Mexicana, 126(e1444), 1-20. https://doi. org/10.21829/abm126.2019.1444

Auffret, A. G., Rico, Y., Bullock, J. M., Hooftman, D. A. P., Pakeman, R. J., Soons, M. B., Suárez-Esteban, A., Traveset, A., Wagner, H. H., y Cousins, S. A. O. (2017). Plant functional connectivity integrating landscape structure and effective dispersal. Journal of Ecology, 105(6), 1648-1656. https://doi.org/10.1111/13652745.12742

Badillo-Montaño, R., Aguirre, A., y Munguía-Rosas, M. A. (2019). Pollinator-mediated interactions between cultivated papaya and co-flowering plant species. Ecology and Evolution, 9(1), 587-597. https://doi.org/10.1002/ece3.4781

Bankova, V., Popova, M., y Trusheva, B. (2018). The phytochemistry of the honeybee. Phytochemistry, 155, 1-11. https://doi. org/10.1016/j.phytochem.2018.07.007

Bonet, F. M., y Vergara, C. H. (2016). Abejas silvestres de un cafetal orgánico en Veracruz, México. Universidad de las Américas Puebla. Escuela de Ciencias. Colección Sapientias.

Cadena, R. Y. J., Vázquez-Sánchez, M., Cruz-Cárdenas, G., y Villaseñor. J. L. (2019). Use of Ecological Niche Models of Plant Species to Optimize Placement of Apiaries. Journal of Apicultural Science, 63(2), 243-265. https://doi.org/10.2478/jas-2019-0017

Canto, A., Herrera, C. M., y Rodriguez, R. (2017). Nectar-living yeasts of a tropical host plant community: Diversity and effects on community-wide floral nectar traits. PeerJ, 2017(7), 1-22. https://doi.org/10.7717/peerj.3517

Castellanos-Potenciano, B. P., Ramírez-Arriaga, E., y Zaldivar-Cruz, J. M. (2012). Análisis del contenido polínico de Mieles (Apidae) en el estado de Tabasco, México. Acta Zoológica Mexicana, 28(1), 13-36

Clarke, D., Morley, E., y Robert, D. (2017). The bee, the flower, and the electric field: electric ecology and aerial electroreception. Journal of Comparative Physiology A: Neuroethology, Sensory, Neural, and Behavioral Physiology, 203(9), 737-748. https:// doi.org/10.1007/s00359-017-1176-6

Contreras-Oliva, A., Pérez-Sato, J. A., Gómez-Merino, F. C., LópezGaray, L. A., Villanueva-Gutiérrez, R., Crosby-Galván, M. G., y Trejo-Téllez, L. I. (2018). Characterization of Scaptotrigona mexicana pot-pollen from Veracruz, México. In P. Vit, S. R. M. Pedro, y D. W. Roubik (Eds.), Pot-Pollen in Stingless Bee Melittology (pp. 325-337). https://doi.org/10.1007/978-3-31961839-5

Giannini, T. C., Araujo, A. D., Alves, R., Duran, C. G., Campbell, A. J., Awade, M., Simões, B. J. M., Saraiva, A. M., elmperatriz-Fonseca, V. L. (2020). Unveiling the contribution of bee pollinators to Brazilian crops with implications for bee management. Apidologie, 51(3), 406-421. https://doi.org/10.1007/s13592019-00727-3

Gómez-Pompa, A., Krömer, T., y Castro-Cortés, R. (2010). Atlas de la Flora de Veracruz: Un patrimonio natural en peligro. México, Gobierno del Estado de Veracruz, Comisión del Estado de Veracruz para la Conmemoración de la Independencia Nacional y la Revolución Mexicana, Universidad Veracruzana. $528 \mathrm{p}$. 
González-Suárez, M., Mora-Olivgio, V., y Guerra-Pérez, A. (2020). Diversidad de la flora de interés apícola en el estado de Tamaulipas, México. Revista Mexicana de Ciencias Pecuarias, 11(3), 914-932. https://doi.org/10.22319/rmcp.v11i3.4717

Gónzalez, R. R. M. (2014). Evaluación de Gymnopodium floribundium Rolfe como recurso nectarífero. Centro de Investigación Científica de Yucatán, A. C.

Hernández-Villa, V., Vibrans, H., Uscanga-Mortera, E., y Aguirre-Jaimes, A. (2020). Floral visitors and pollinator dependence are related to floral display size and plant height in native weeds of central Mexico. Flora: Morphology, Distribution, Functional Ecology of Plants, 262,151505. https://doi.org/10.1016/j.flora.2019.151505

Herrera-López, M. G., Rubio-Hernández, E. I., Leyte-Lugo, M. A. Schinkovitz, A., Richomme, P., Calvo-Irabién, L. M., y PeñaRodríguez, L. M. (2019). Botanical origin of triterpenoids from Yucatecan propolis. Phytochemistry Letters, 29, 25-29. https:// doi.org/10.1016/j.phytol.2018.10.015

Hipólito, J., Viana, B. F., y Garibaldi, L. A. (2016). The value of pollinator-friendly practices: Synergies between natural and anthropogenic assets. Basic and Applied Ecology, 17(8), 659667. https://doi.org/10.1016/j.baae.2016.09.003

Kevan, P., y Silva, P. N. (2020). Pollination and Agriculture. Encyclopedia of Social Insects, 1-9. https://doi.org/10.1007/978-3-31990306-4_176-1

Kremen, C., y M'Gonigle, L. K. (2015). Small-scale restoration in intensive agricultural landscapes supports more specialized and less mobile pollinator species. Journal of Applied Ecology, 52(3), 602-610. https://doi.org/10.1111/1365-2664.12418

Landaverde-González, P., Quezada-Euán, J. J. G., Theodorou, P., Murray, T. E., Husemann, M., Ayala, R., Moo-Valle, H., Vandame, R., y Paxton, R. J. (2017). Sweat bees on hot chillies: provision of pollination services by native bees in traditional slash-andburn agriculture in the Yucatán Peninsula of tropical Mexico. Journal of Applied Ecology, 54(6), 1814-1824. https://doi. org/10.1111/1365-2664.12860

Leonhardt, S. D., Dworschak, K., Eltz, T., y Blüthgen, N. (2007). Foraging loads of stingless bees and utilisation of stored nectar for pollen harvesting. Apidologie, 38(2), 125-135. https://doi.org/10.1051/ apido:2006059

Martínez-Adriano, C. A., Aguirre-Jaimes, A., y Díaz-Castelazo, C. (2016). Floristic survey of flowering plants in a tropical coastal ecosystem in Veracruz, Mexico. Botanical Sciences, 94(1), 185 197. https://doi.org/10.17129/botsci.272

Martínez-Adriano, C. A., Díaz-Castelazo, C., y Aguirre-Jaimes, A. (2018). Flower-mediated plant-butterfly interactions in an heterogeneous tropical coastal ecosystem. PeerJ, 2018(9). https://doi.org/10.7717/peerj.5493

Meléndez, R. V., Ayala, R., y Delfín, G. H. (2018). Crop pollination by stingless bees. In P. Vit, S. R. M. Pedro, y D. W. Roubik (Eds.), Pot-Pollen in Stingless Bee Melittology (pp. 139-153). https:// doi.org/10.1007/978-3-319-61839-5

Montoya-Bonilla, B. P., Baca- Gamboa, A. E., y Bonilla, B. L. (2017). Flora melifera y su oferta de recursos en cinco veredas del municipio de Piendamó, Cauca. Biotecnología En El Sector Agropecuario y Agroindustrial, 1, 20-28. https://doi.org/10.18684/BSAA
Parra-Tabla, V., Angulo-Pérez, D., Albor, C., Campos-Navarrete, M. J., Tun-Garrido, J., Sosenski, P., Alonso, C., Ashman, T. L., y ArceoGómez, G. (2019). The role of alien species on plant-floral visitor network structure in invaded communities. PLoS ONE, 14(11), 1-19. https://doi.org/10.1371/journal.pone.0218227

Ramírez-Arriaga, E., Pacheco-Palomo, K. G., Moguel-Ordoñez, Y. B., Zepeda, G. M. R., y Godínez-García, L. M. (2018). Angiosperm resources for stingless bees (Apidae, Meliponini): A pot-pollen melittopalynological study in the gulf of Mexico. In P. Vit, S R. M. Pedro, y D. W. Roubik (Eds.), Pot-Pollen in Stingless Bee Melittology (pp. 111-130). Springer International Publishing AG. https://doi.org/10.1007/978-3-319-61839-5

Ramírez-Arriaga, Elia, Martínez-Bernal, A., Maldonado, N. R., y MartínezHernández, E. (2016). Palynological analysis of honeys and pollen loads of Apis mellifera (Apidae) from the central and northern regions of the state of Guerrero, Mexico. Botanical Sciences, 94(1), 141-156. https://doi.org/10.17129/botsci.217

Ramírez-Bravo, O. E., y Hernández-Santin, L. (2016). Plant diversity along a disturbance gradient in a semi-arid ecosystem in Central Mexico. Acta Botanica Mexicana, 117, 11-25. https:// doi.org/10.21829/abm117.2016.1164

Stephen, A. (2014). Pollen - A microscopic wonder of plant kingdom. International Journal of Advanced Research in Biological Sciences, 1(9), 127-130.

Thakur, M., y Nanda, V. (2020). Composition and functionality of bee pollen: A review. Trends in Food Science and Technology, 98, 82-106. https://doi.org/10.1016/j.tifs.2020.02.001

Ulloa, C. U., Acevedo-Rodríguez, P., Beck, S., Belgrano, M. J., Bernal, R., Berry, P. E., Brako, L., Celis, M., Davidse, G., León-yánez, S., Magill, R. E., Neill, D. A., Nee, M., Raven, P. H., Stimmel, H., Strong, M. T., Villaseñor, J. L., Zarucchi, J. L., Zuloaga, F. O., y Jørgensen, P. M. (2017). An integrated assessment of the vascular plant species of the Americas. Science, 358, 1614-1617.

Villaseñor, J. L. (2016). Catálogo de las plantas vasculares nativas de México. Revista Mexicana de Biodiversidad, 87(3), 559-902. https://doi.org/10.1016/j.rmb.2016.06.017

Villegas, D. G., Bolaños, M. A., Miranda, S. J., Sandoval, H. R., y Lizama, M. J. M. (2000). Flora nectarifera y polinifera en el estado de Veracruz. Secretaria de Agricultura, Ganadería y Desarrollo Rural. https://atlasapi2019.github.io/pdfs/FloraNectarifera y polinifera Chiapas.pdf

Von, T. J., Manson, R. H., Congalton, R. G., López-Barrera, F., y Jones, K. W. (2021). Evaluating the environmental effectiveness of payments for hydrological services in Veracruz, México: A landscape approach. Land Use Policy, 100. https://doi. org/10.1016/j.landusepol.2020.105055

Vossler, F. G. (2015). Broad Protein Spectrum in Stored Pollen of Three Stingless Bees from the Chaco Dry Forest in South America (Hymenoptera, Apidae, Meliponini) and Its Ecological Implications. Psyche (London), 2015, 13-15. https://doi org/10.1155/2015/659538

Wilson, J. S., Forister, M. L., y Carril, O. M. (2017). Interest exceeds understanding in public support of bee conservation. Frontiers in Ecology and the Environment, 15(8), 460-466. https://doi. org/10.1002/fee.1531 


\begin{tabular}{|c|c|c|c|c|c|c|c|c|c|c|c|c|c|c|c|c|c|c|c|c|c|c|c|c|c|}
\hline 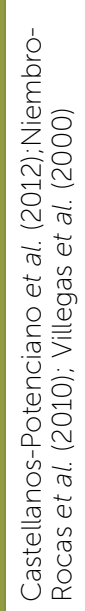 & 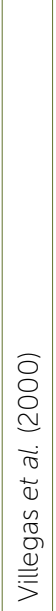 & 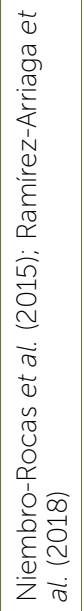 & 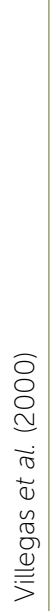 & 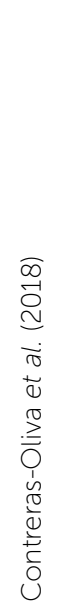 & 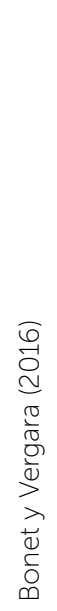 & 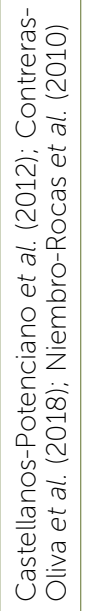 & 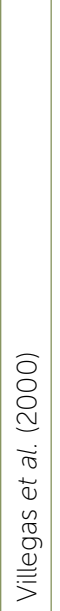 & 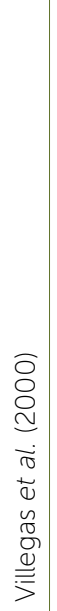 & 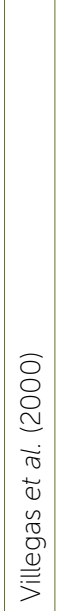 & 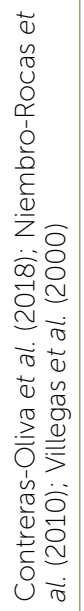 & 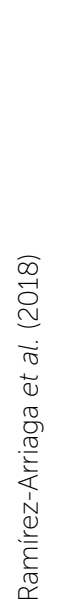 & 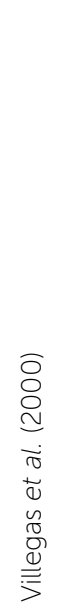 & 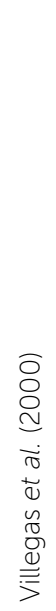 & 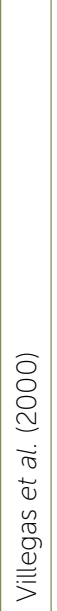 & 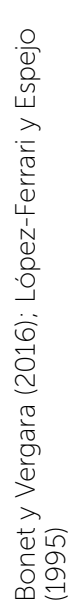 & 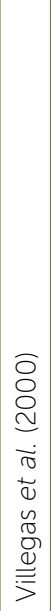 & 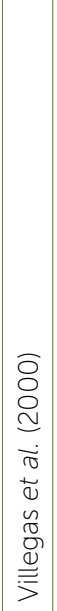 & 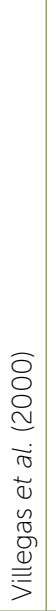 & 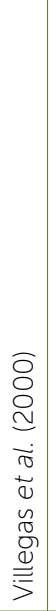 & 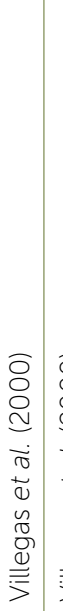 & 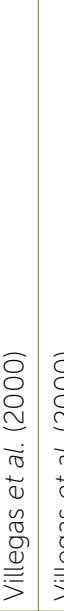 & 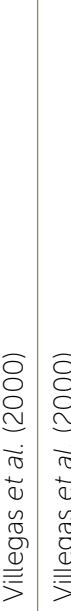 & 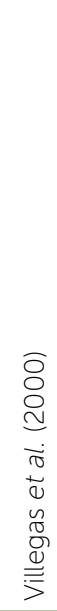 & 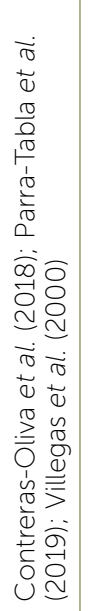 & $\begin{array}{l}\mathbb{U} \\
\vec{\sigma} \\
\mathbb{d} \\
\widetilde{J} \\
\widetilde{\sigma}\end{array}$ \\
\hline 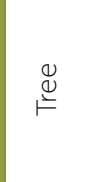 & $\stackrel{\underset{\Perp}{\Perp}}{\stackrel{\Perp}{\Perp}}$ & 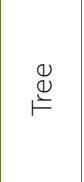 & $\begin{array}{l}\frac{0}{2} \\
\frac{2}{n} \\
\frac{1}{n}\end{array}$ & 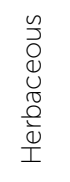 & 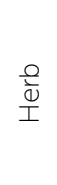 & 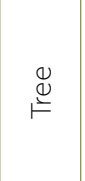 & 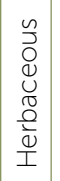 & 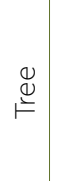 & $\begin{array}{l}\frac{0}{2} \\
\frac{2}{2} \\
\text { s. }\end{array}$ & 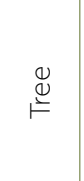 & $\stackrel{\stackrel{\Perp}{\Perp}}{\models}$ & 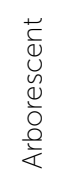 & 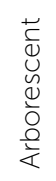 & 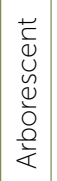 & 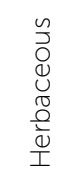 & $\mid \begin{array}{l}\overline{\bar{\nu}} \\
u \\
0\end{array}$ & 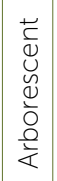 & 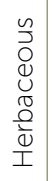 & 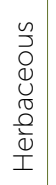 & 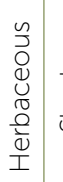 & $\begin{array}{ll}\frac{0}{3} \\
\frac{3}{2} \\
\bar{c}\end{array}$ & 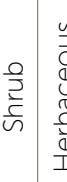 & $\frac{0}{\frac{0}{2}}$ & 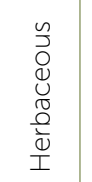 & \\
\hline
\end{tabular}

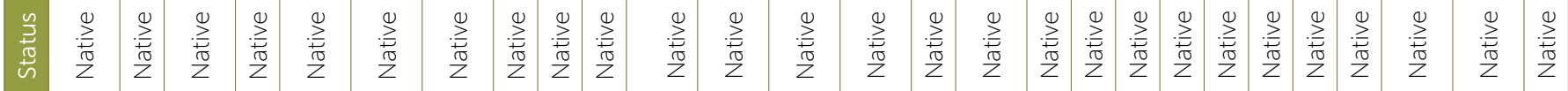

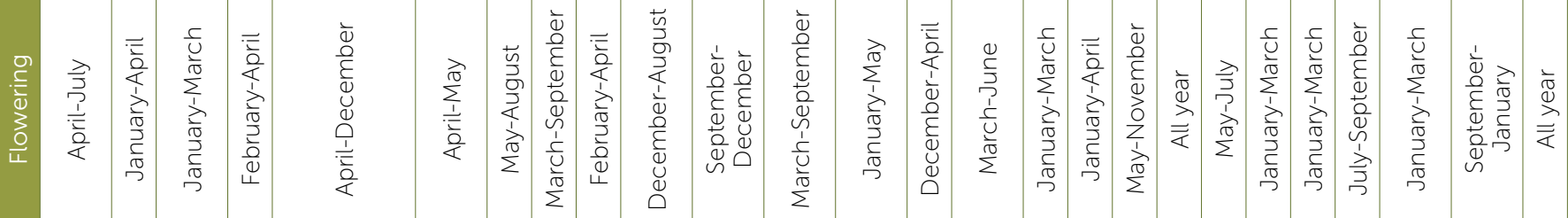

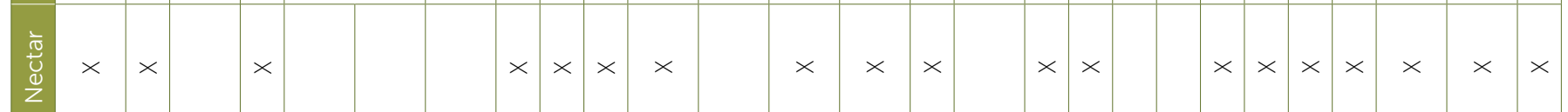

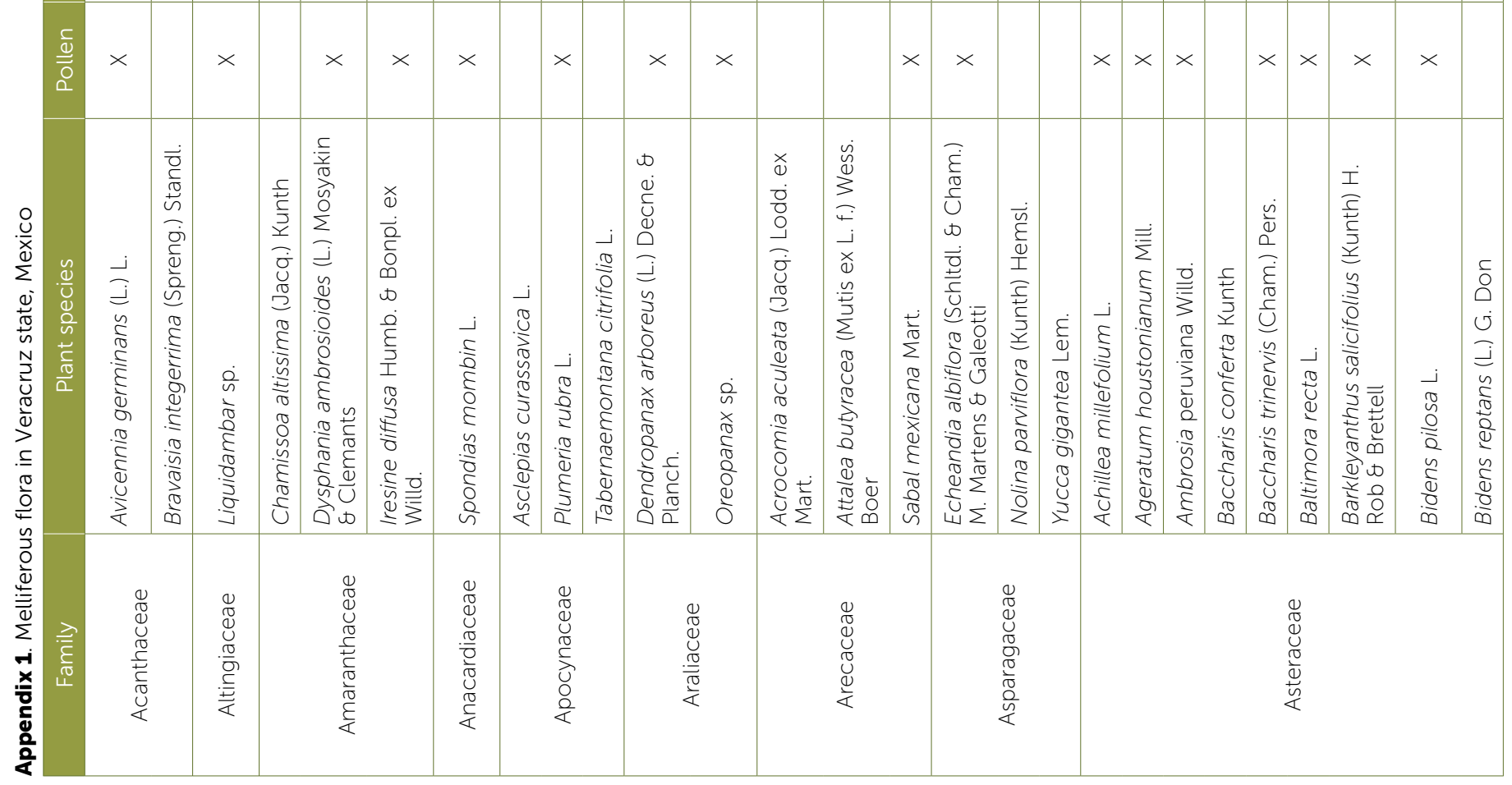




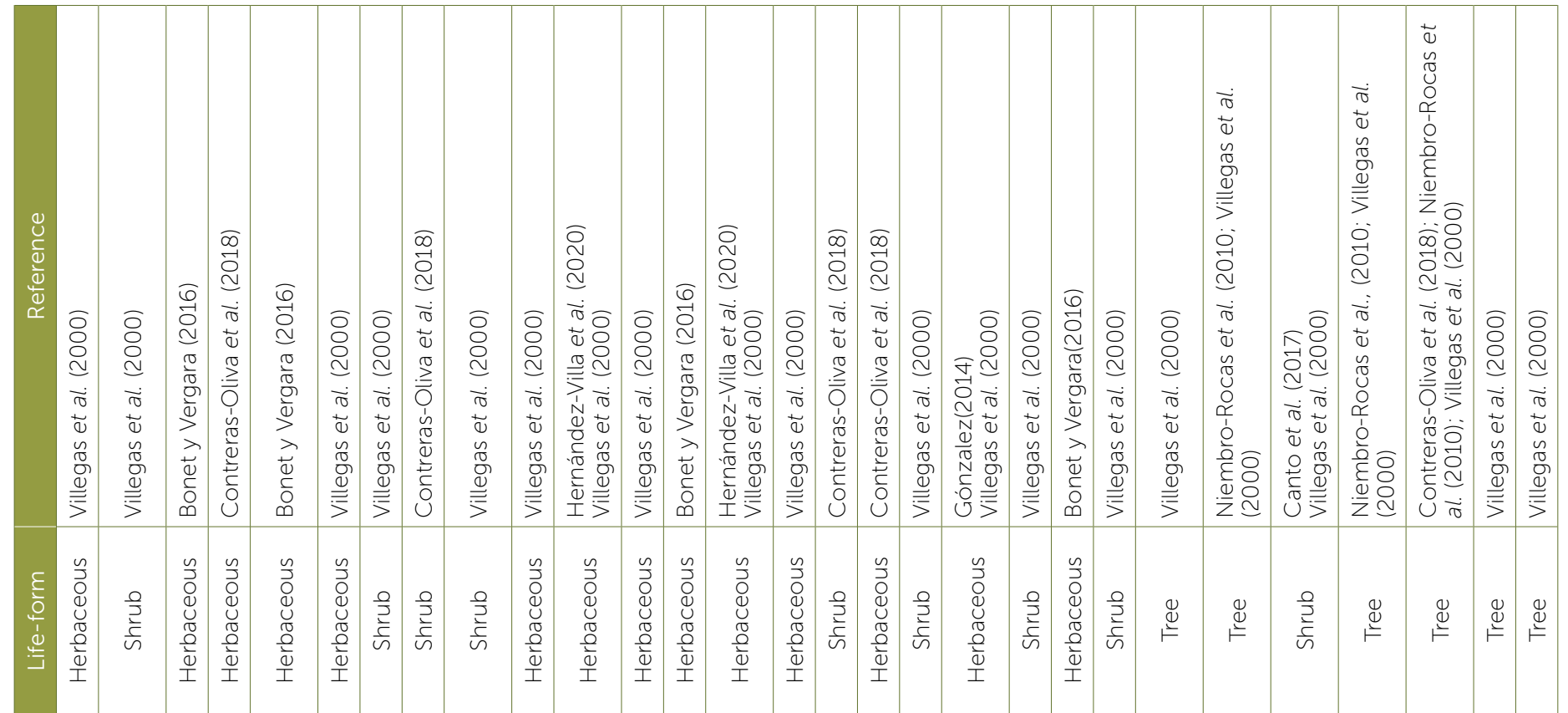

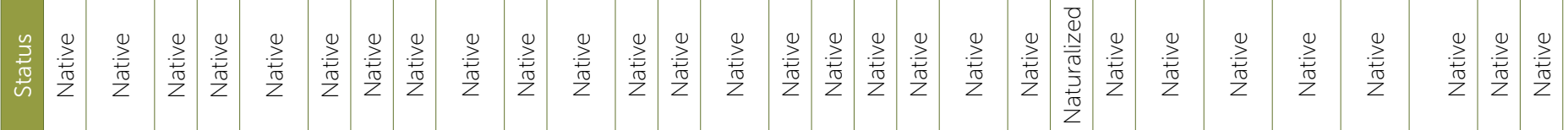

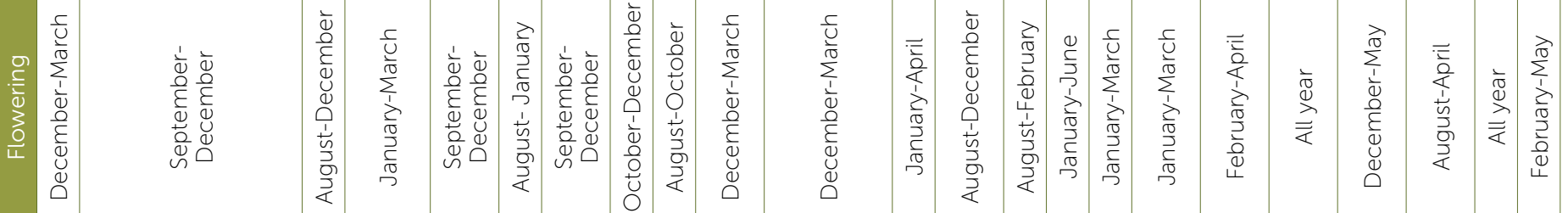

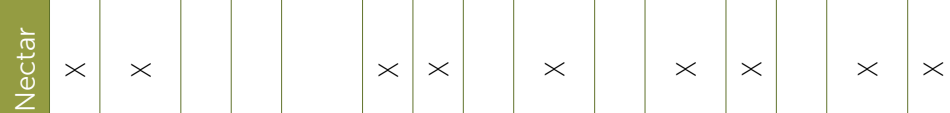
$\times \quad \times \times \times \times \times$ $\times$

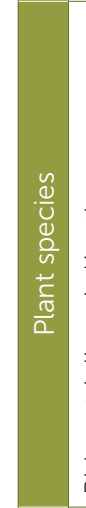

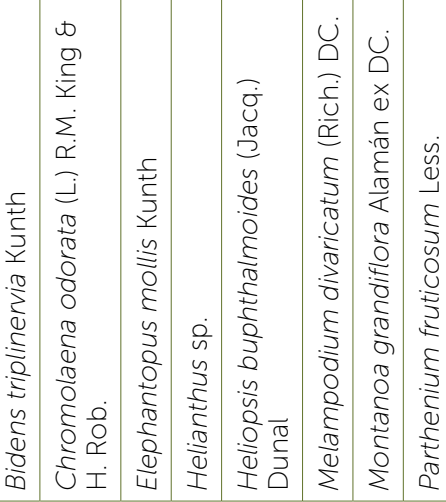

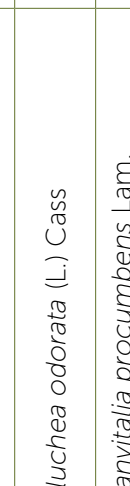
$\times \quad \times \times \times \times \times \times$

\footnotetext{
$\times$
}

$\times$

\begin{tabular}{|l|l|l|l|l|l|l|}
$\times$ & $\times$ & $\times$ & $\times$ & $\times$ & $\times$ & \\
\hline$\times$ & $\times$ & & & $\times$ & & $\times$
\end{tabular}

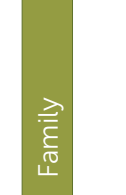

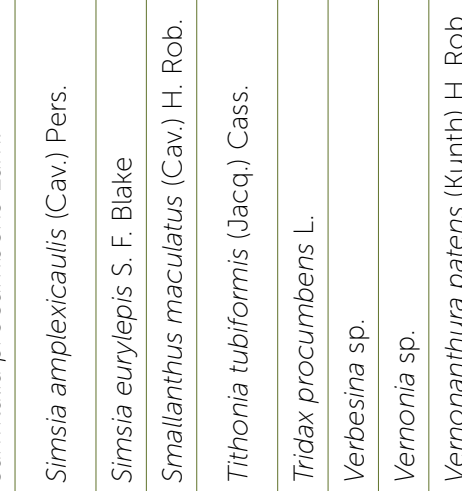
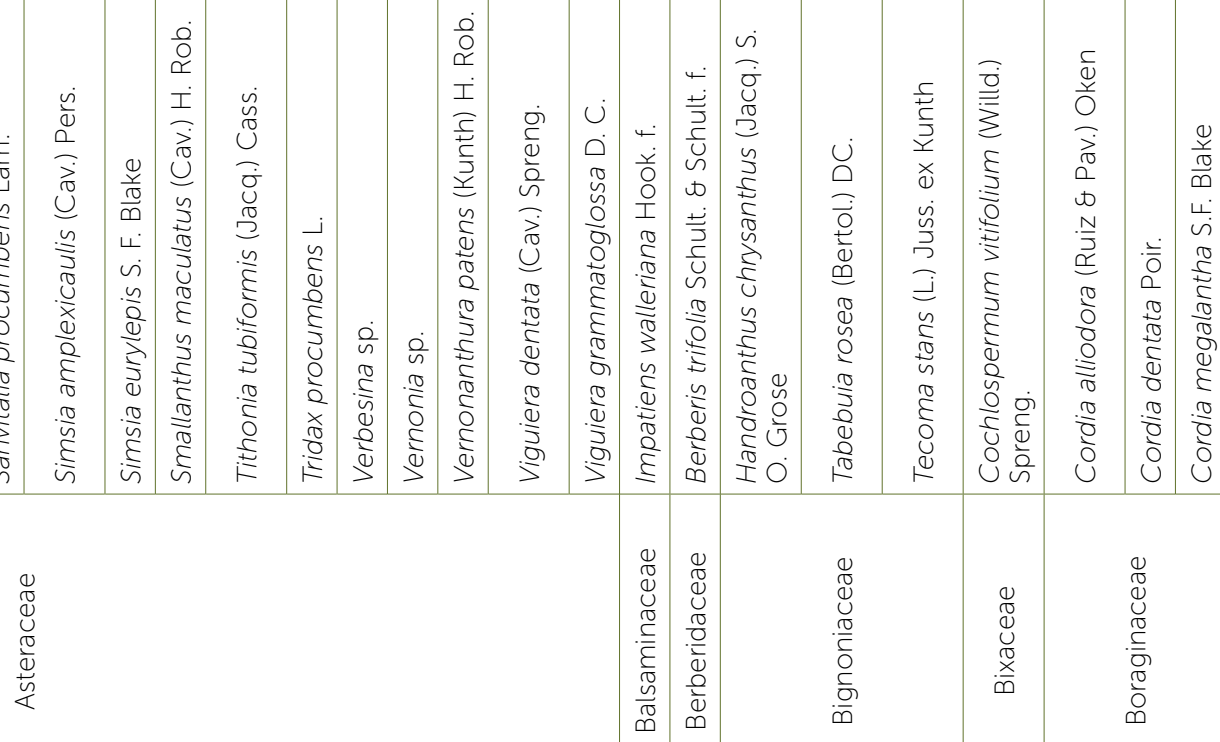


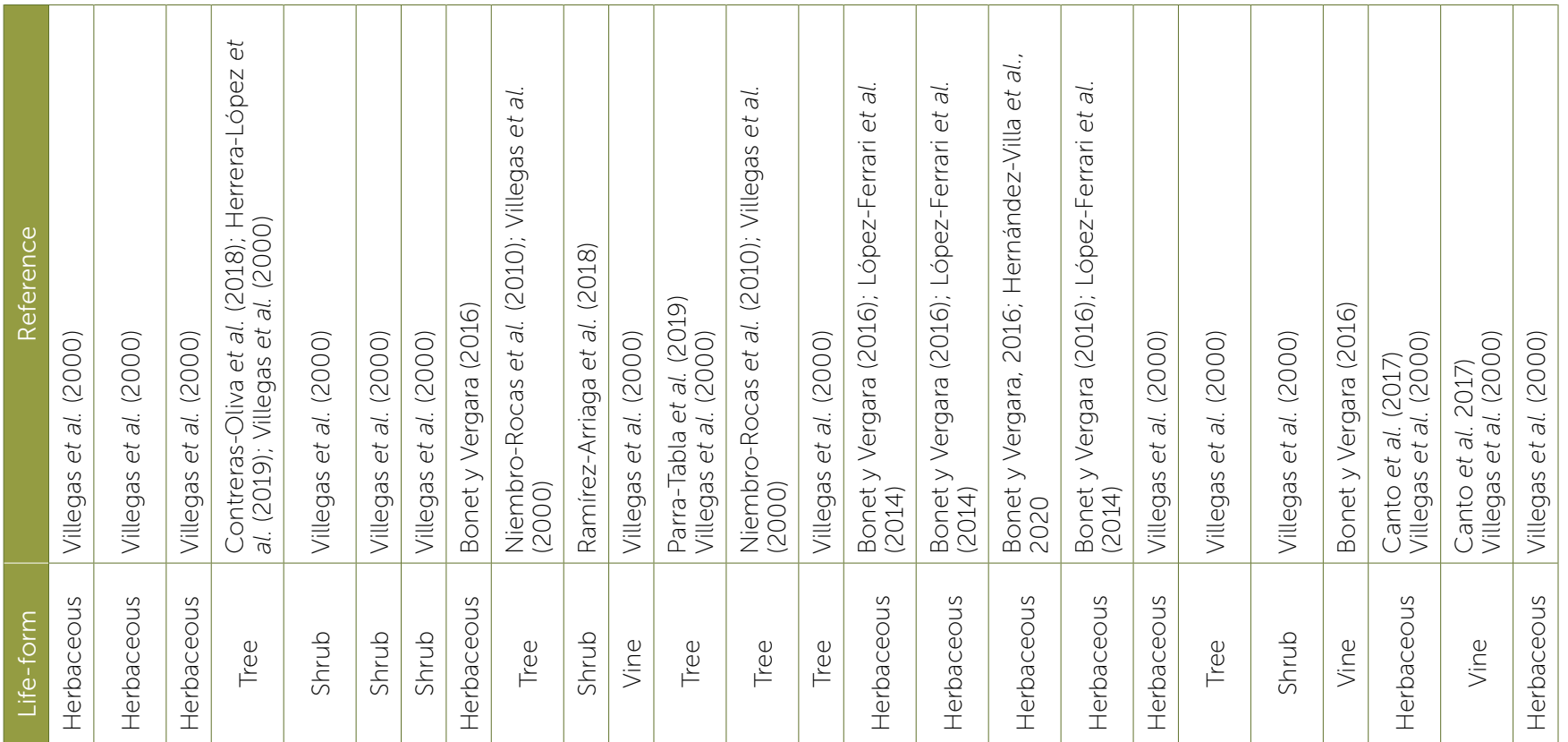

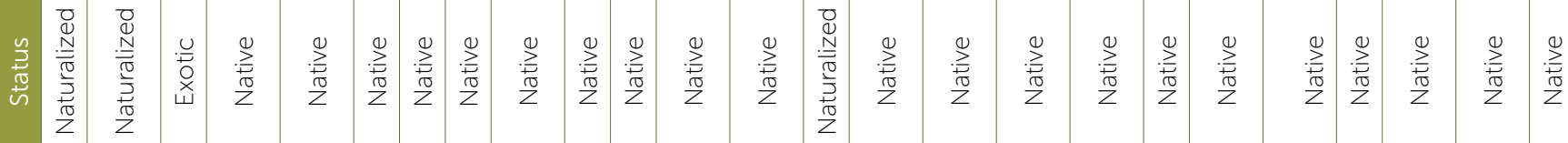

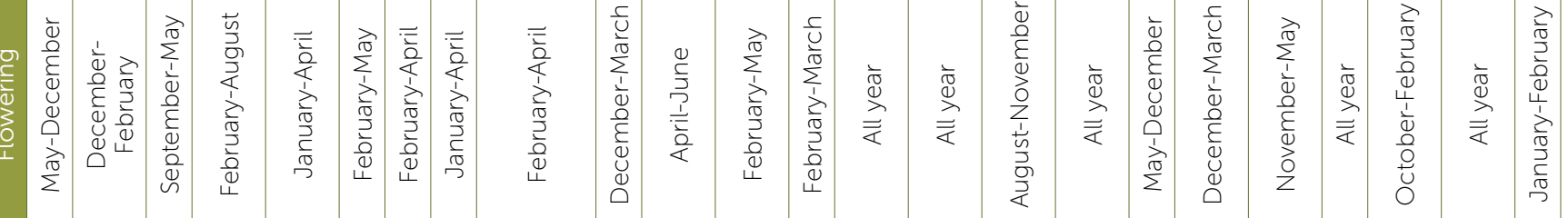
$\times$ $\times$

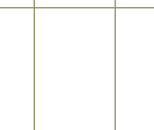
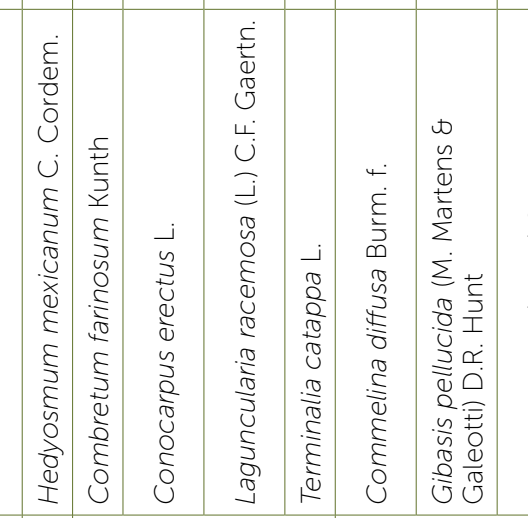

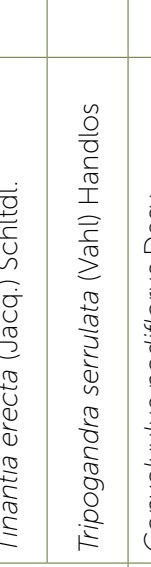
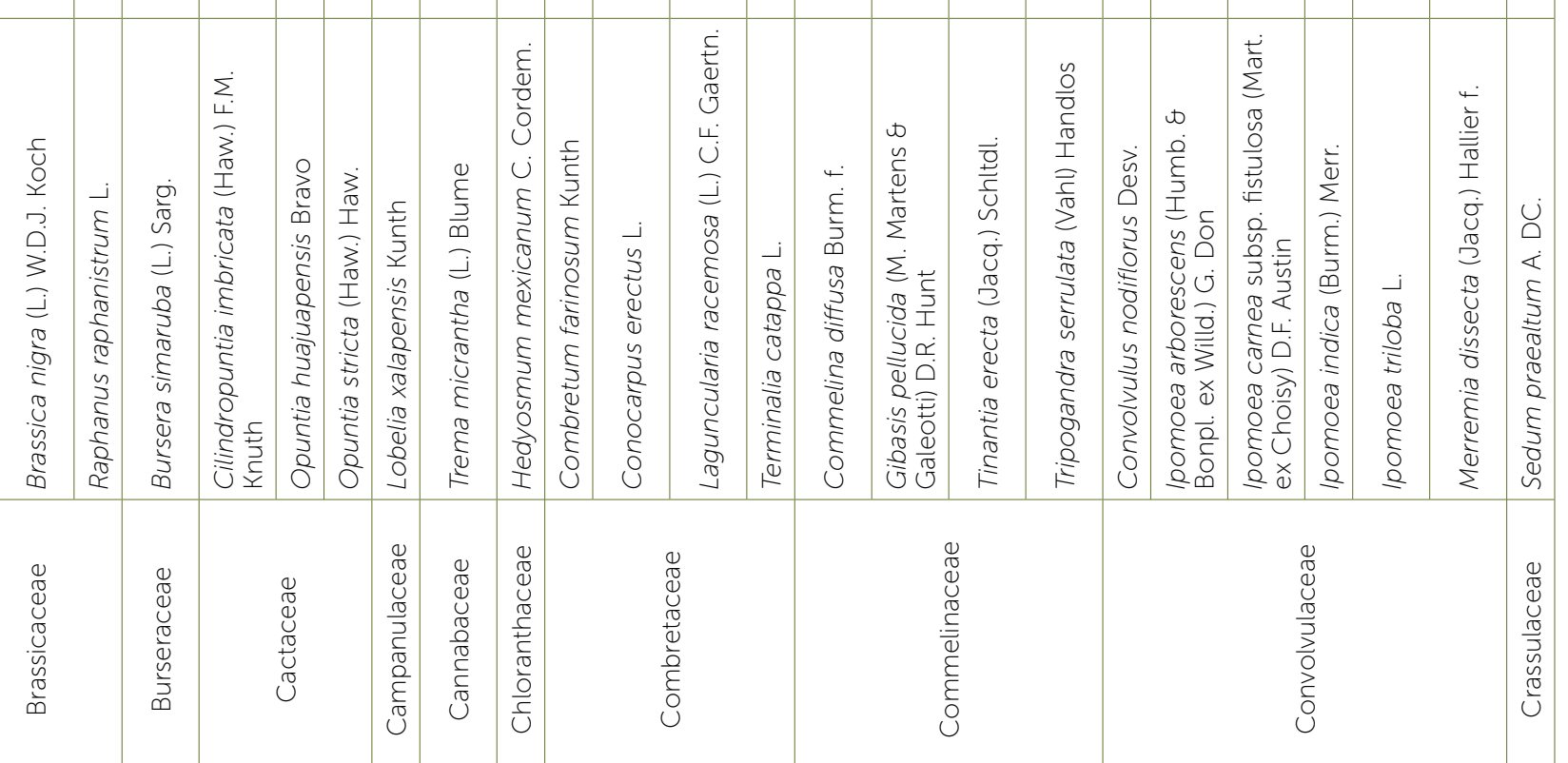


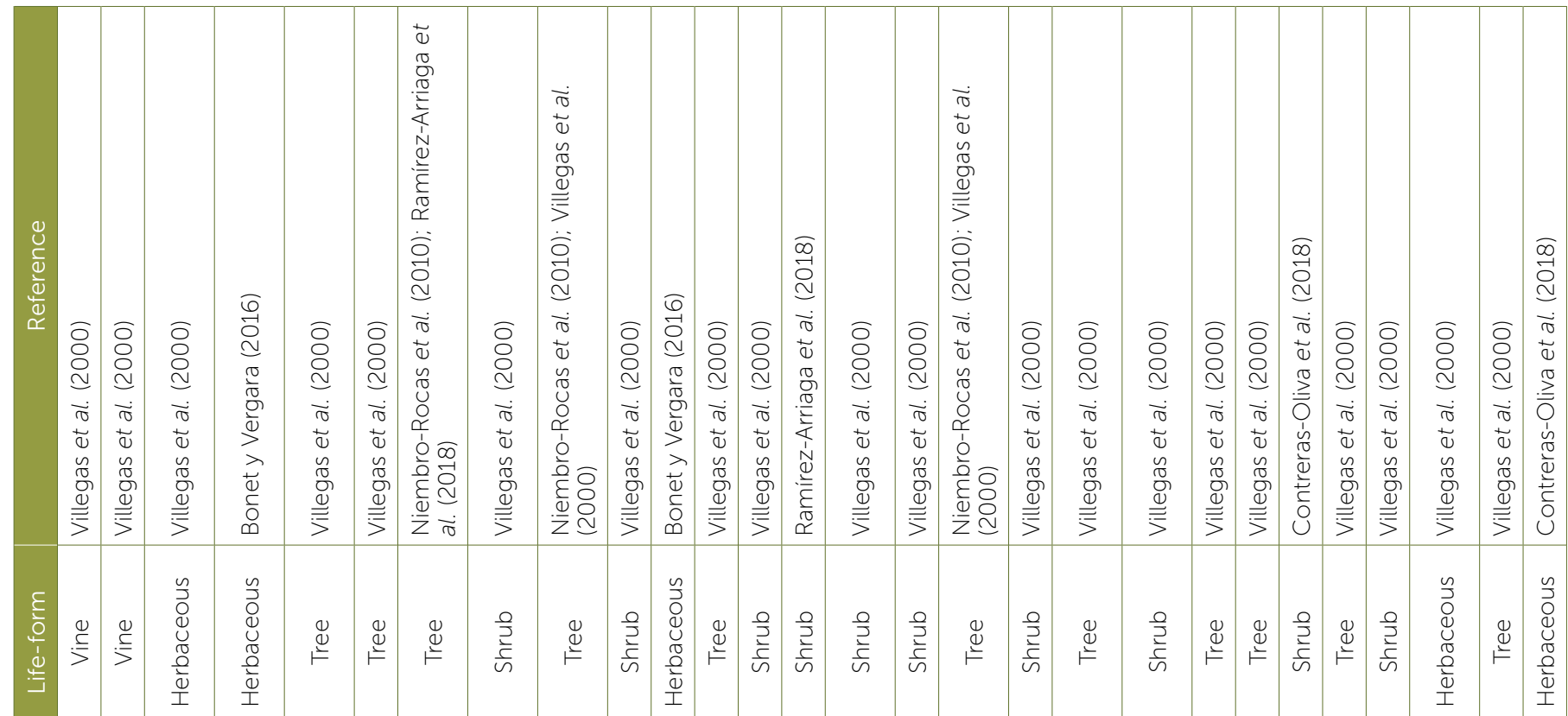

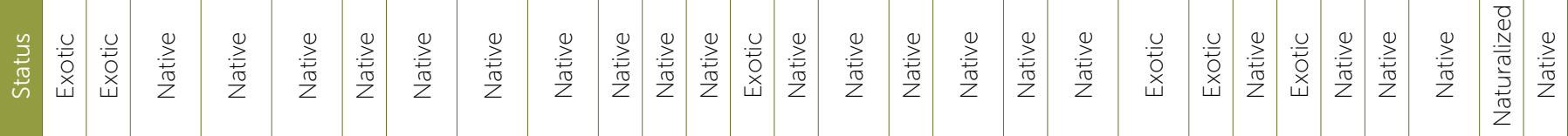

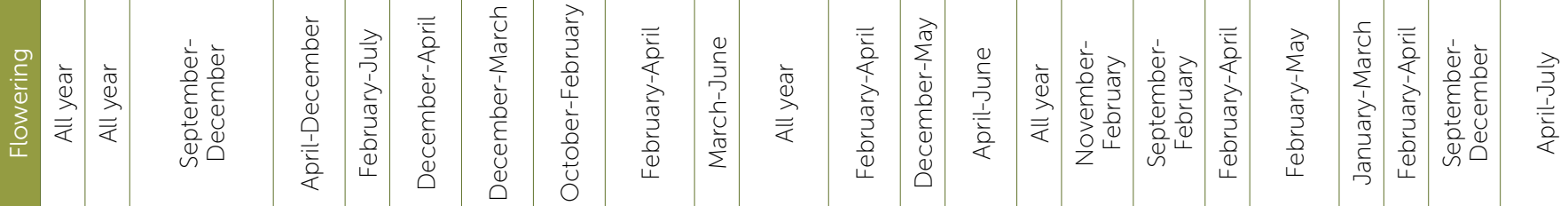

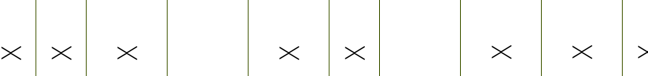

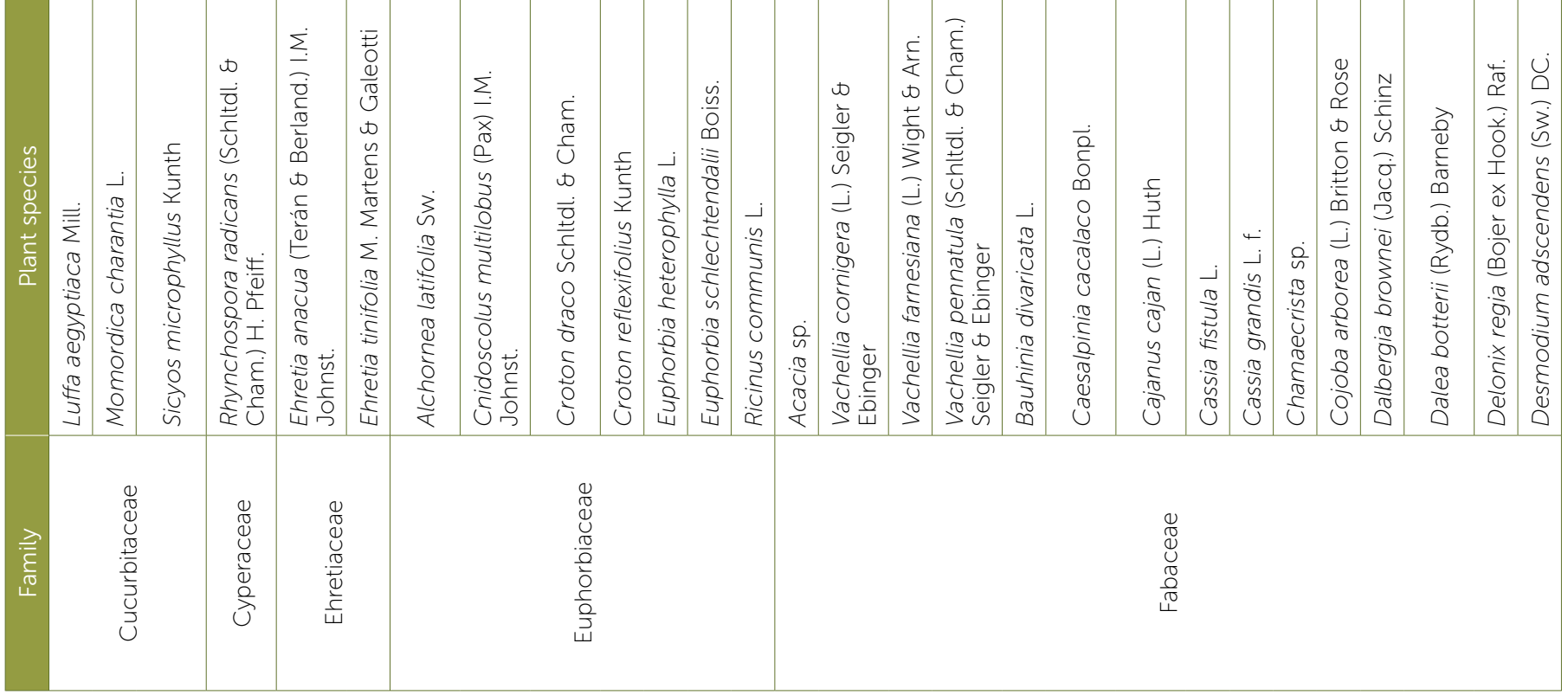




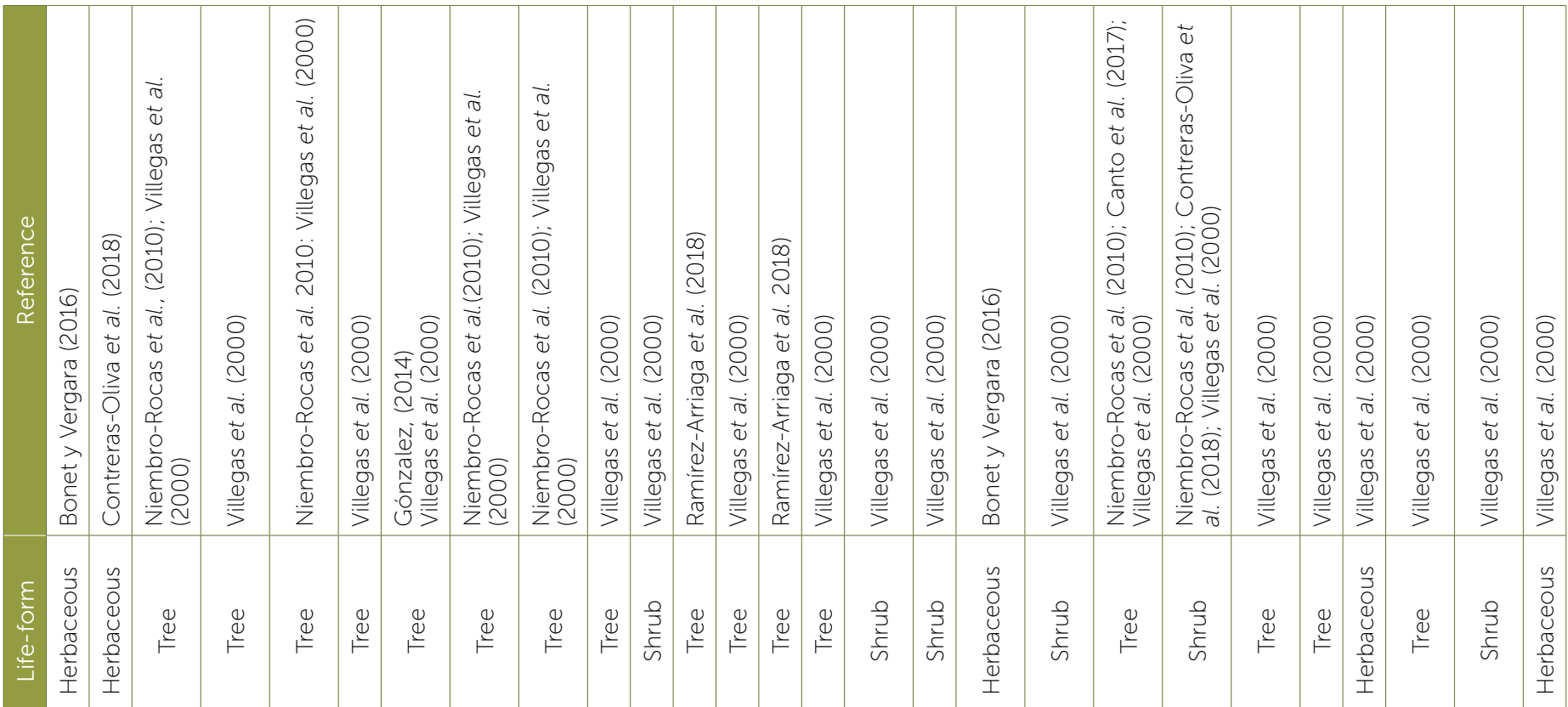

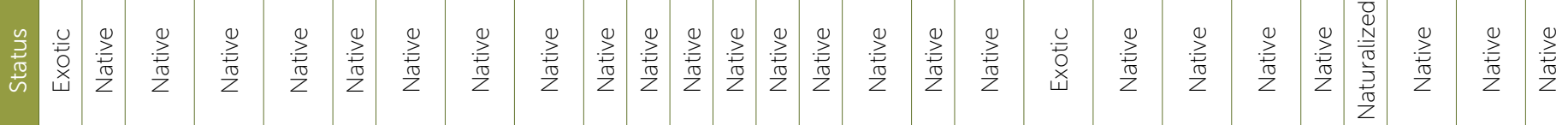

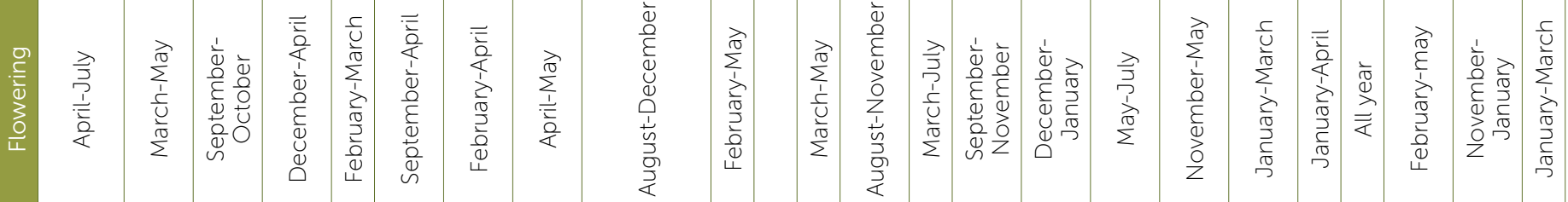

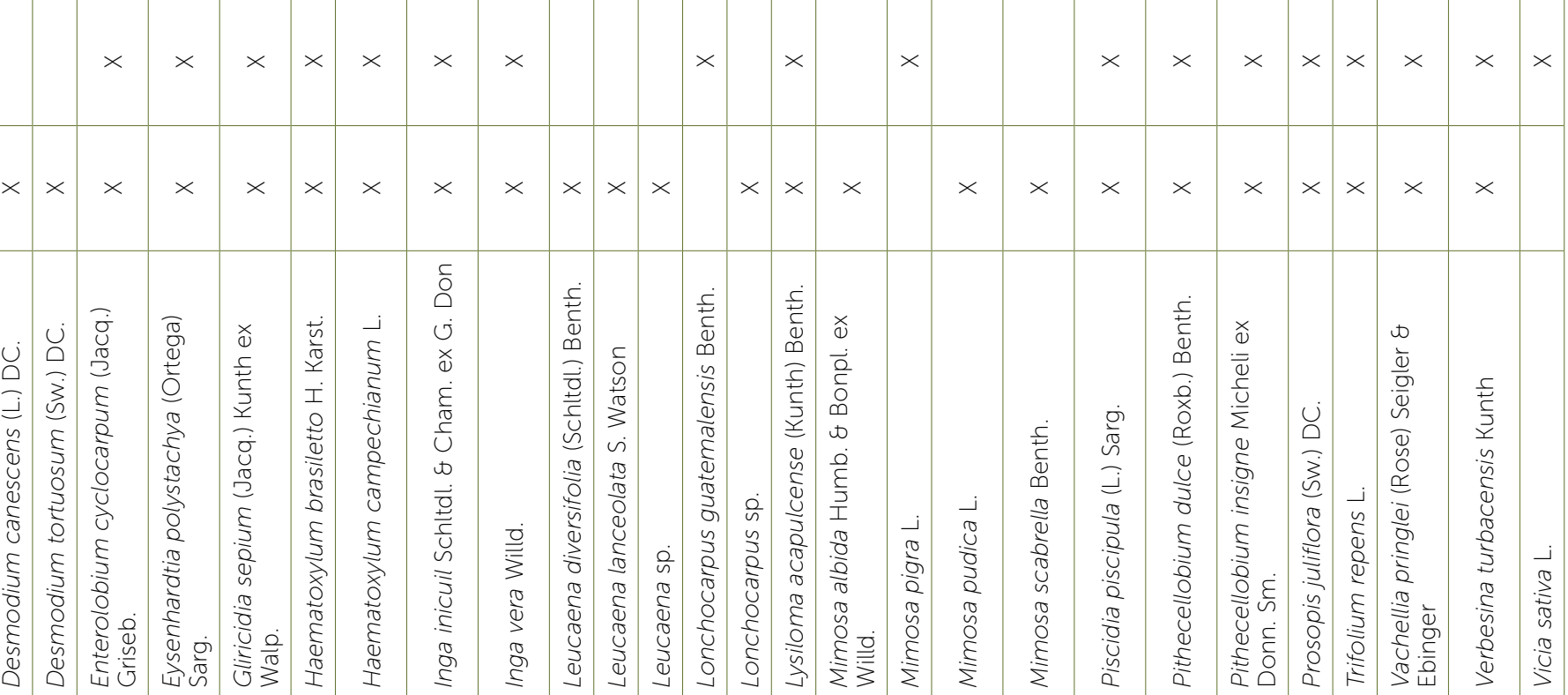


党焉

离

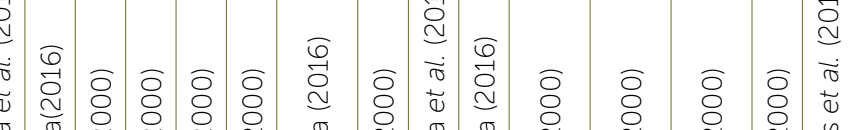

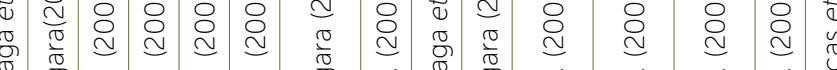

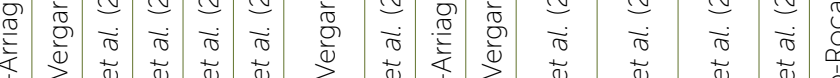

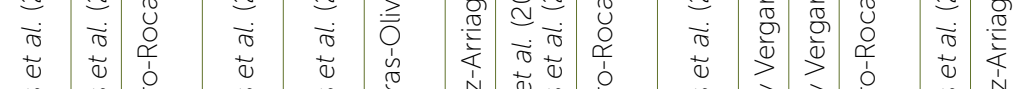

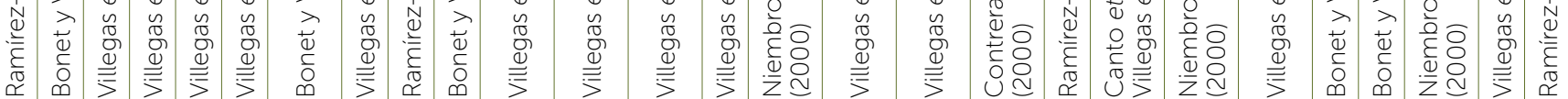

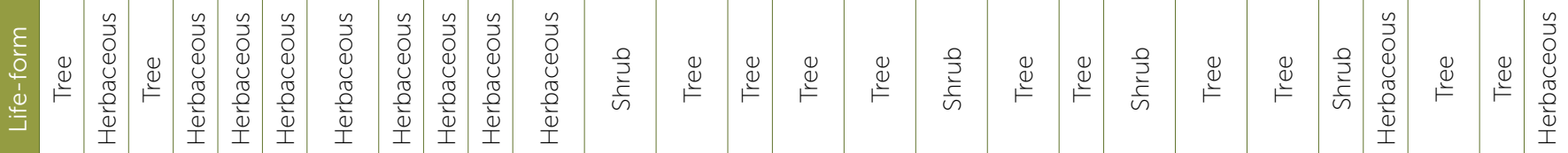

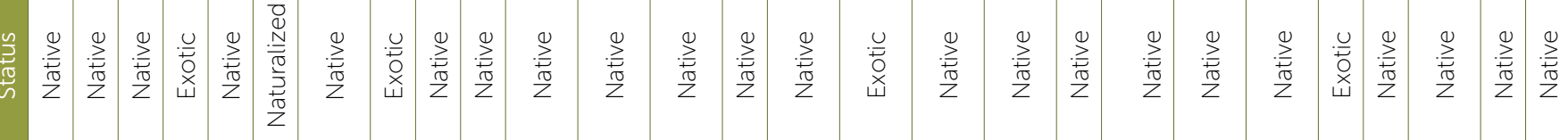

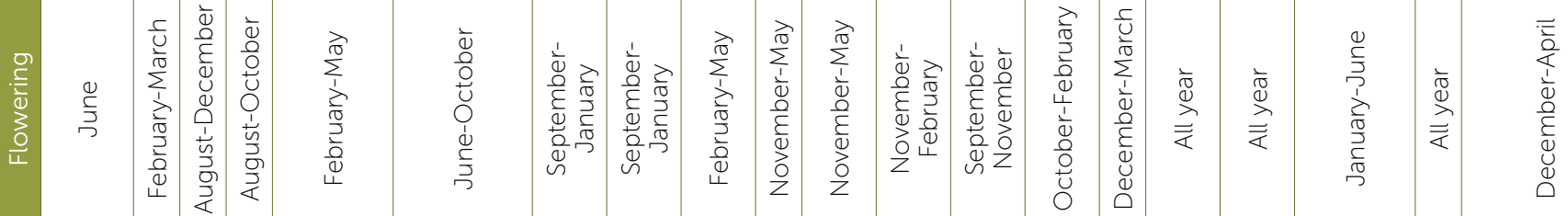

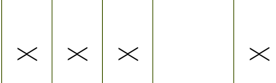

$\frac{\sqrt{9}}{\frac{\pi}{3}}$

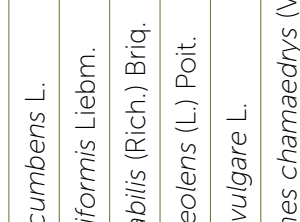

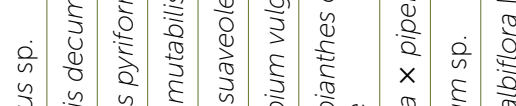

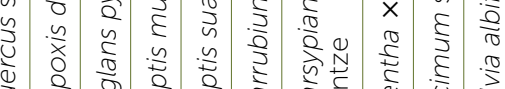

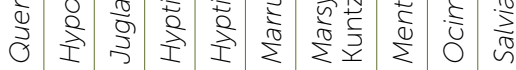

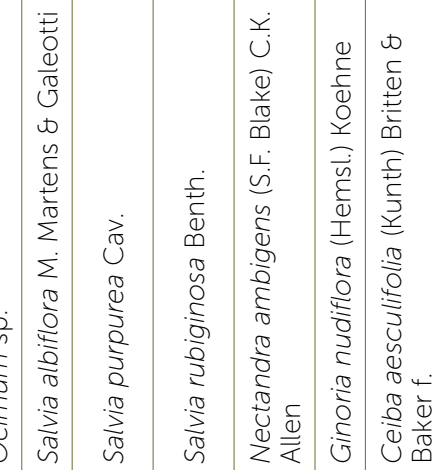

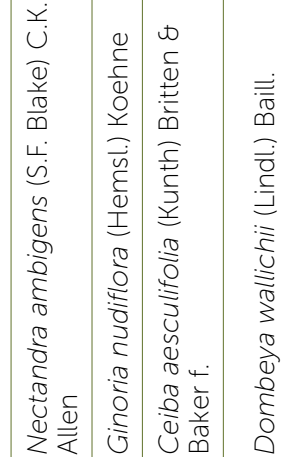

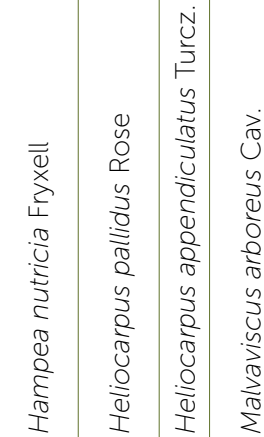

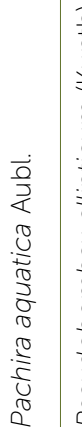

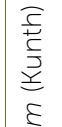

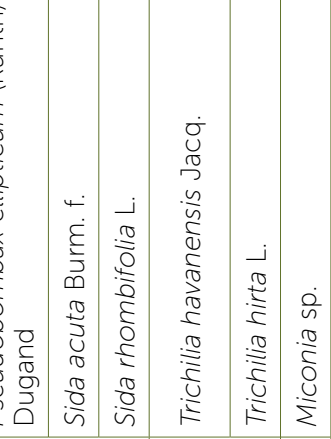

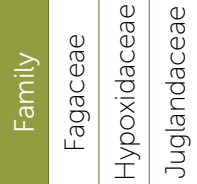

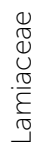

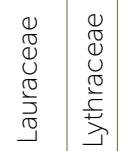

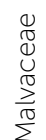

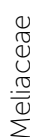

$\underset{\varpi}{\mathbb{N}}$

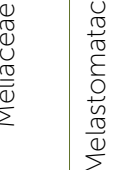




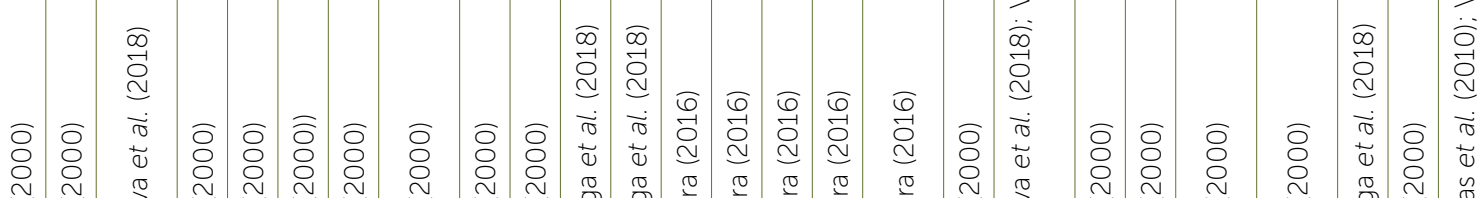

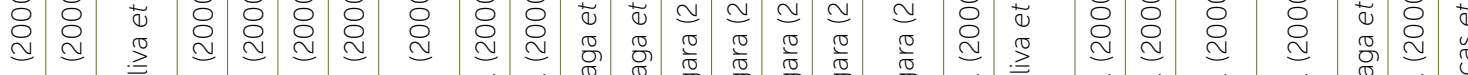

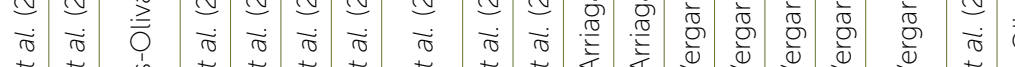

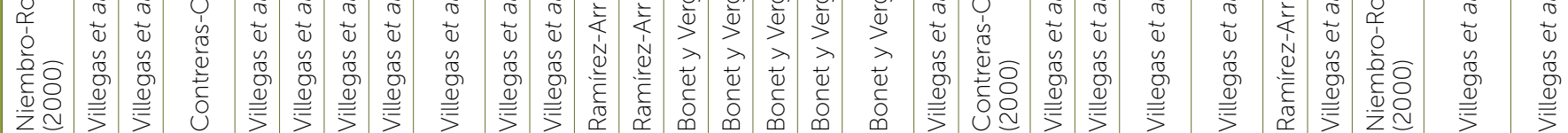

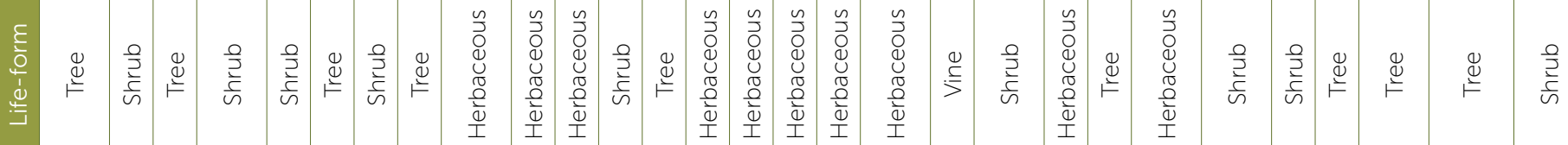

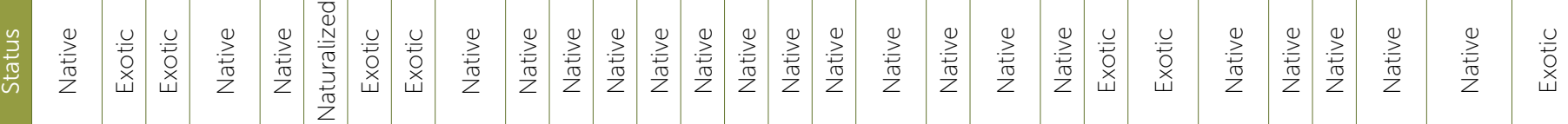

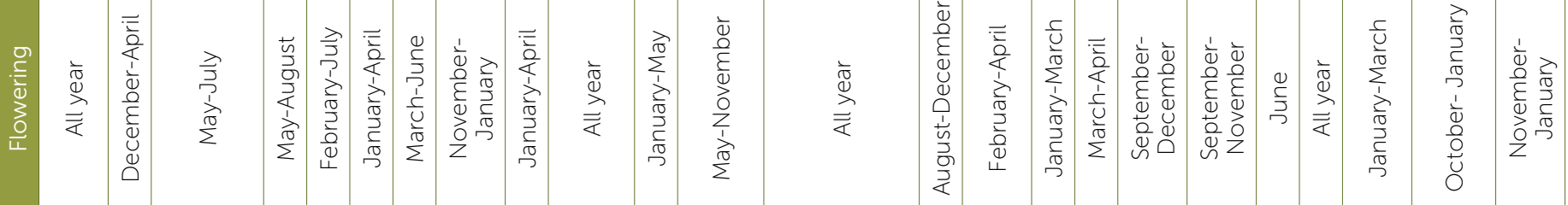

$\times \quad \times \quad \times \quad \times \quad \times \quad \times \quad \times \quad \times \times$

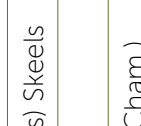

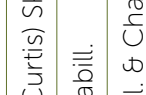

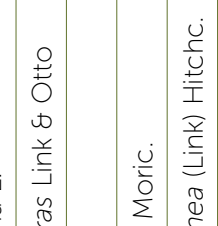

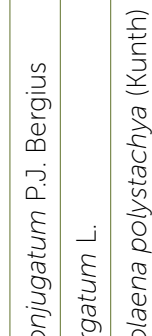

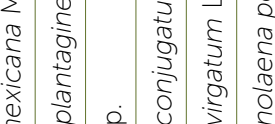

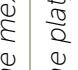

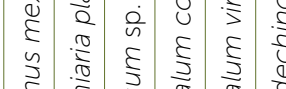

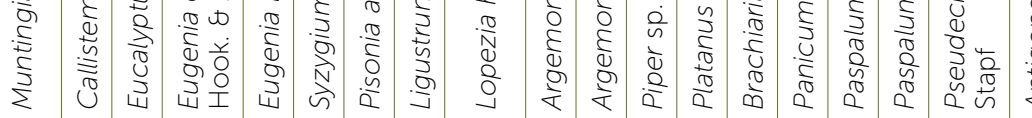

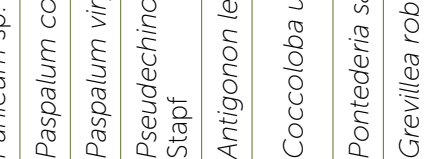

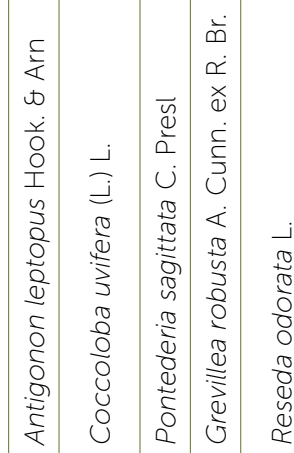

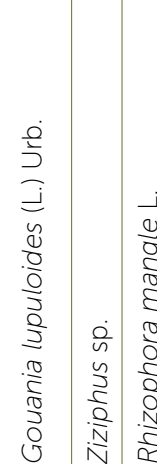

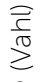

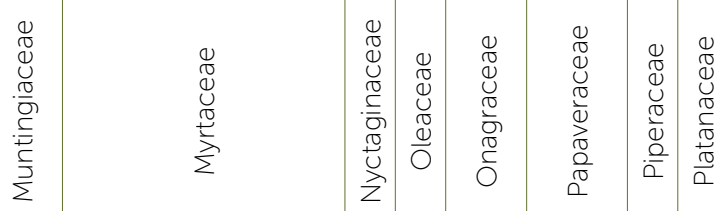

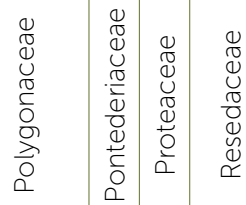

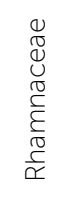

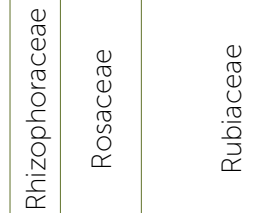




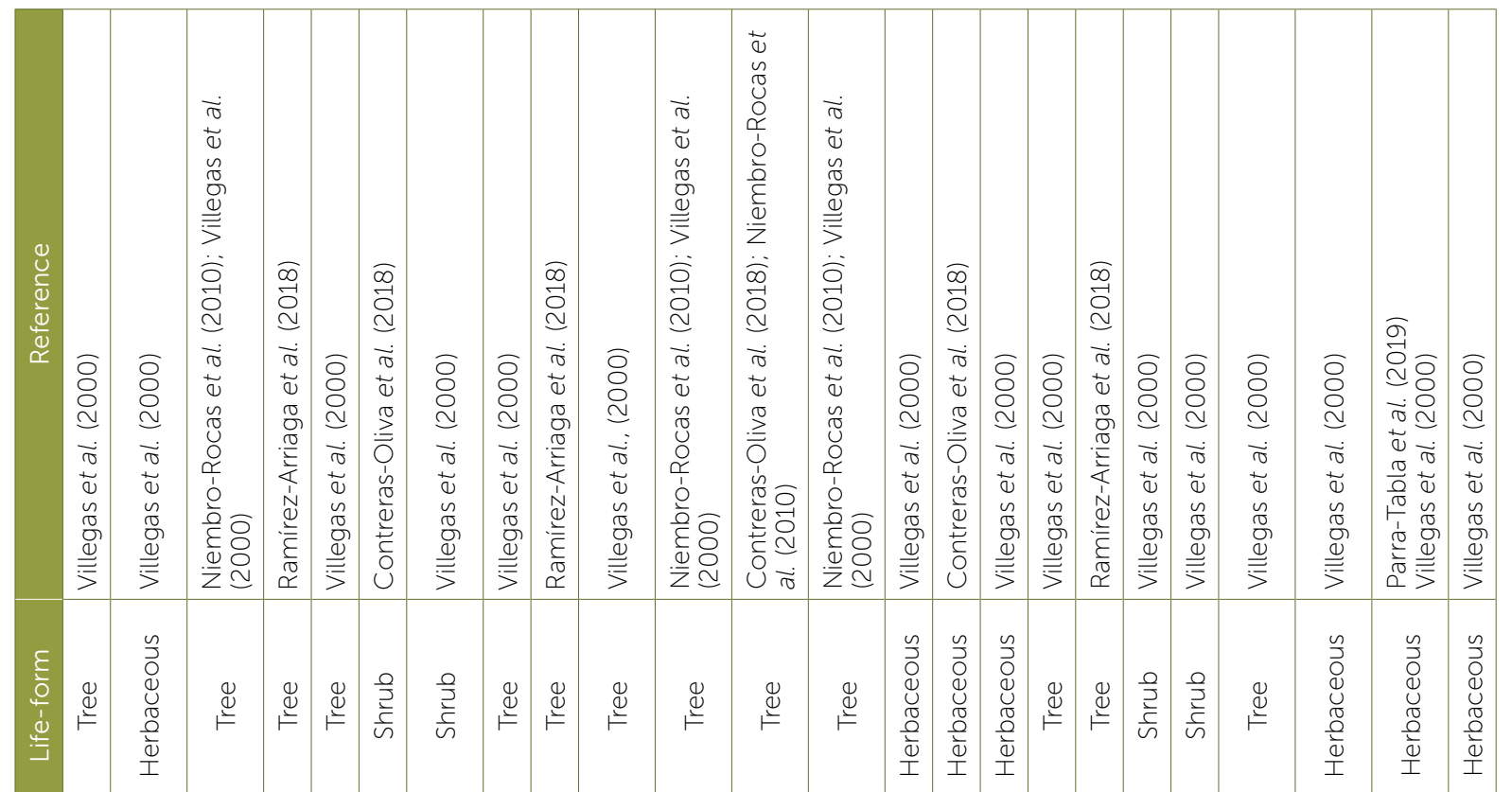

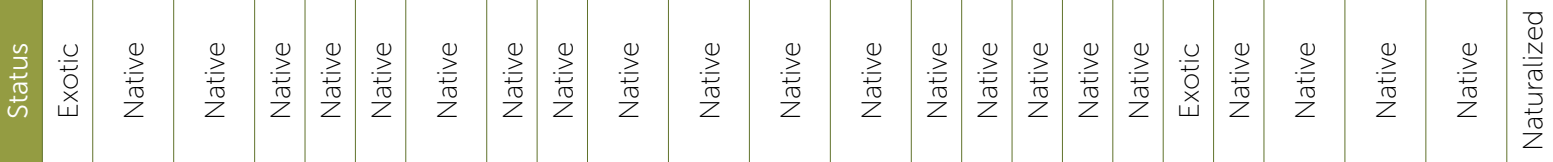

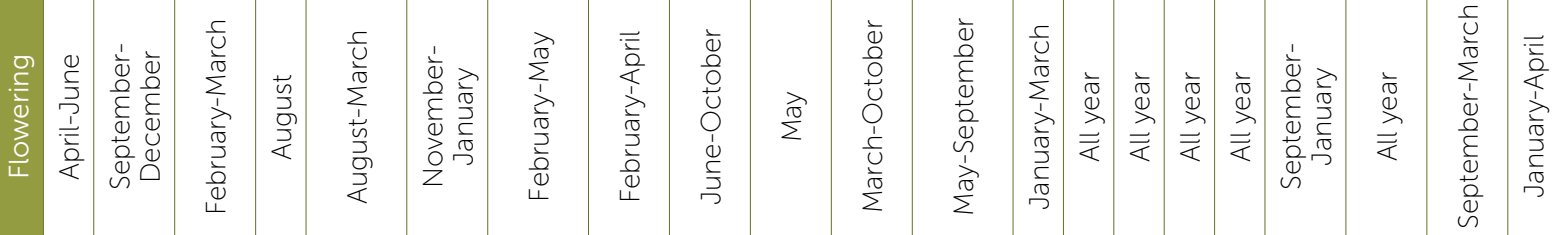

$\times \quad \times \quad \times$

$\times$

\begin{tabular}{l|l|l|l}
$\times$ & $\times$ & $\times$ & $x$
\end{tabular}

$\times$

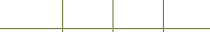

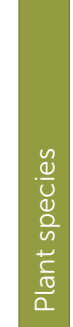

$|+|+\mid$

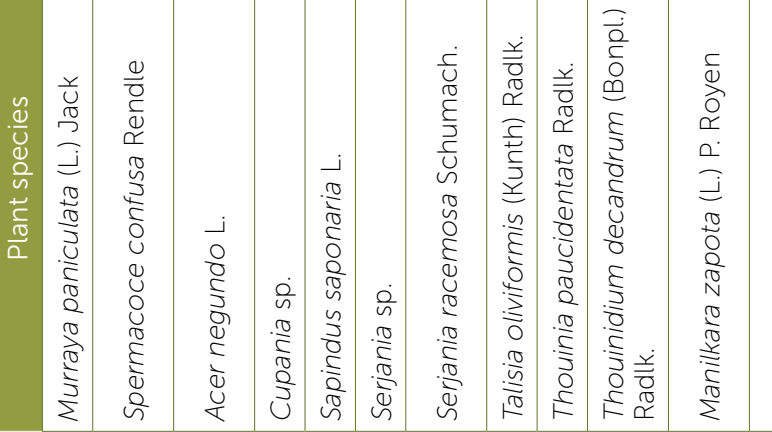

+

\begin{tabular}{l|l|l|l|l|l|}
\hline & & & & & \\
\hline
\end{tabular}




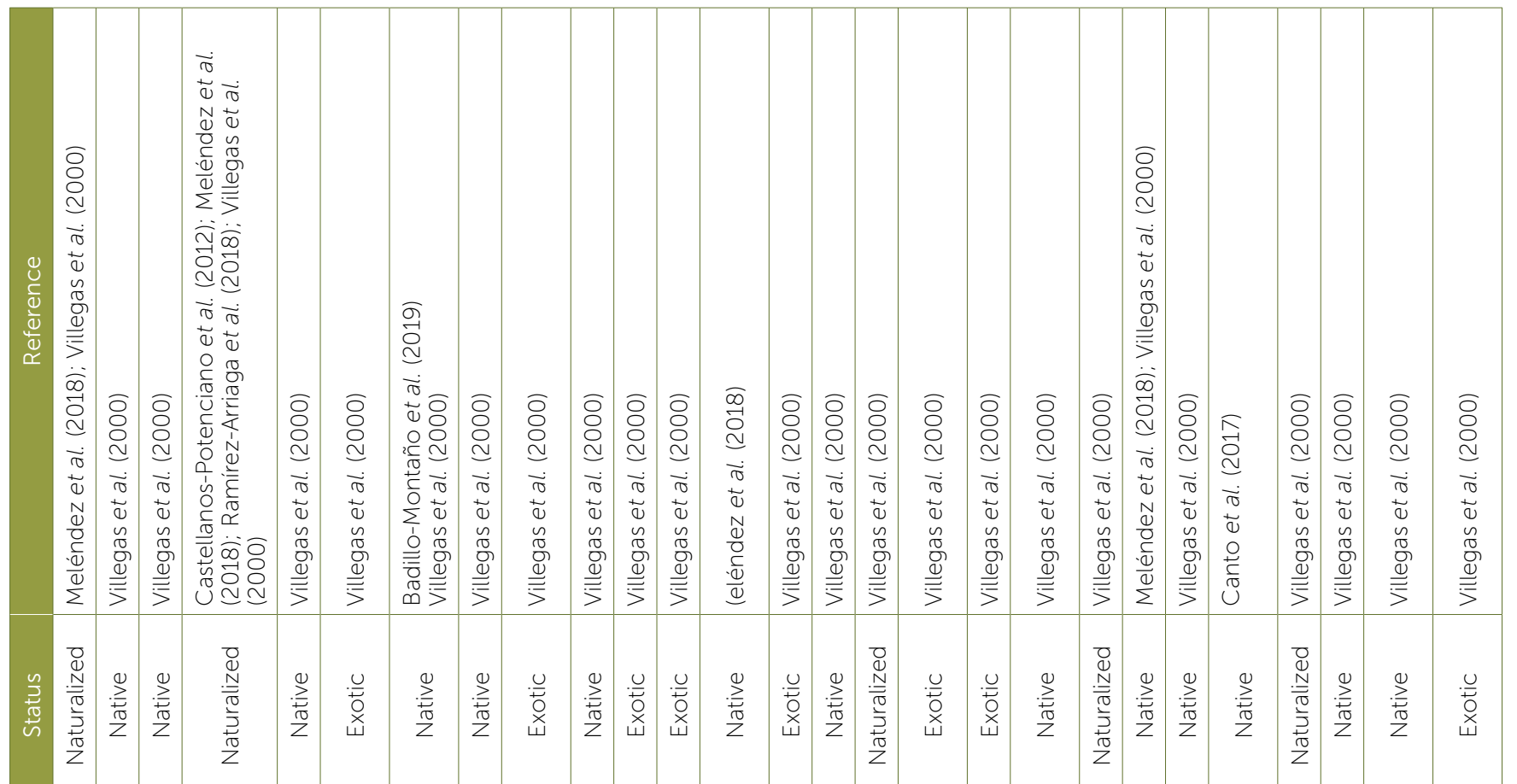

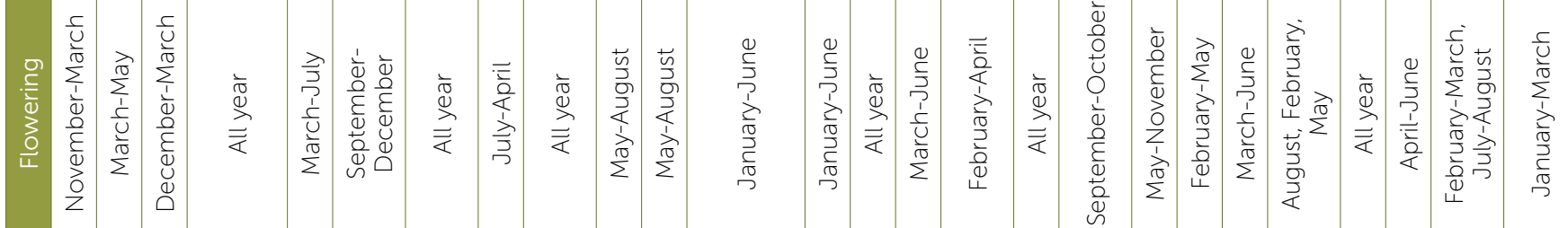

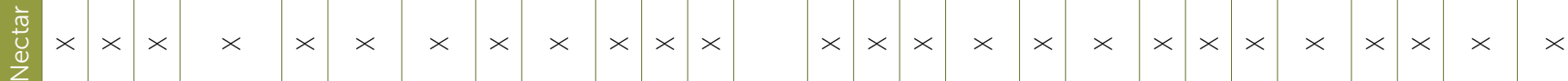
$\stackrel{\frac{c}{\varrho}}{\stackrel{\stackrel{0}{0}}{0}} \times$

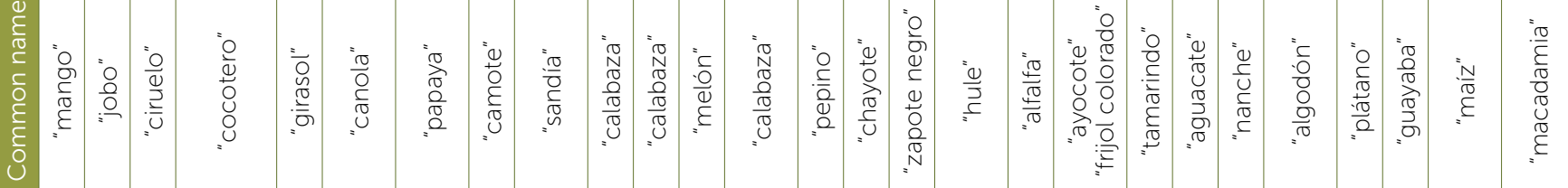

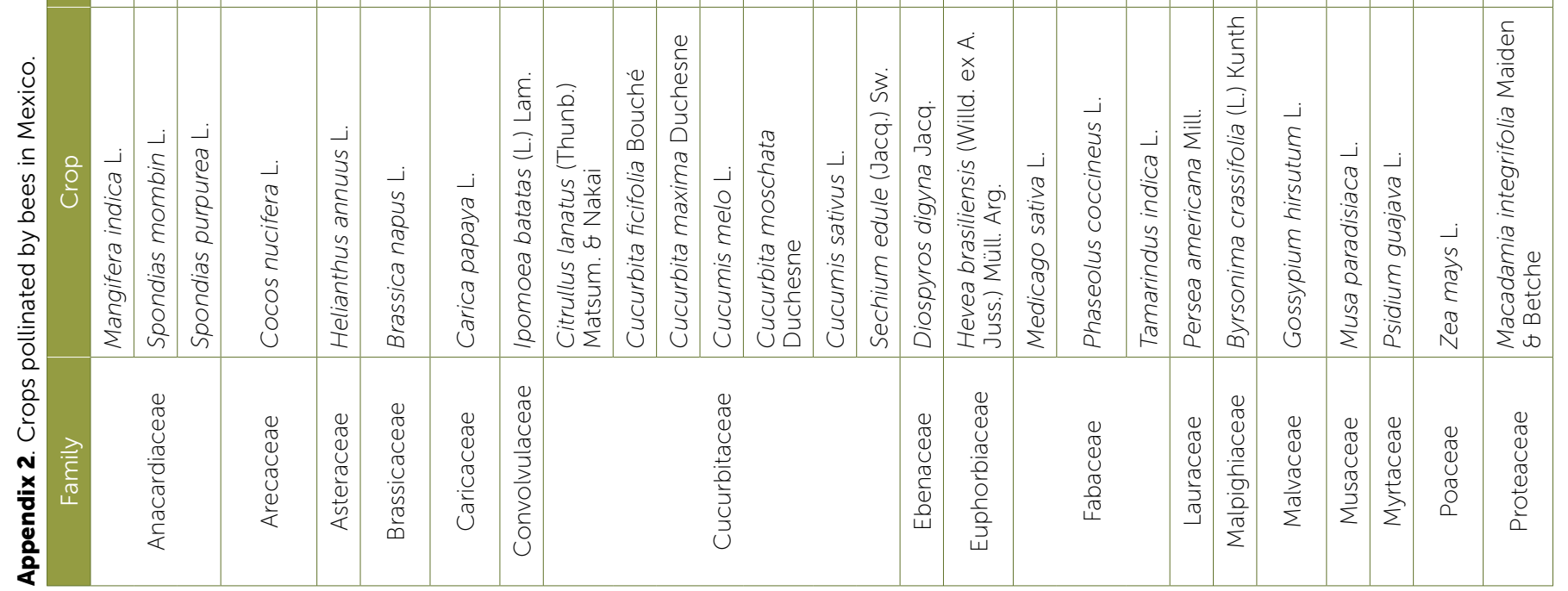




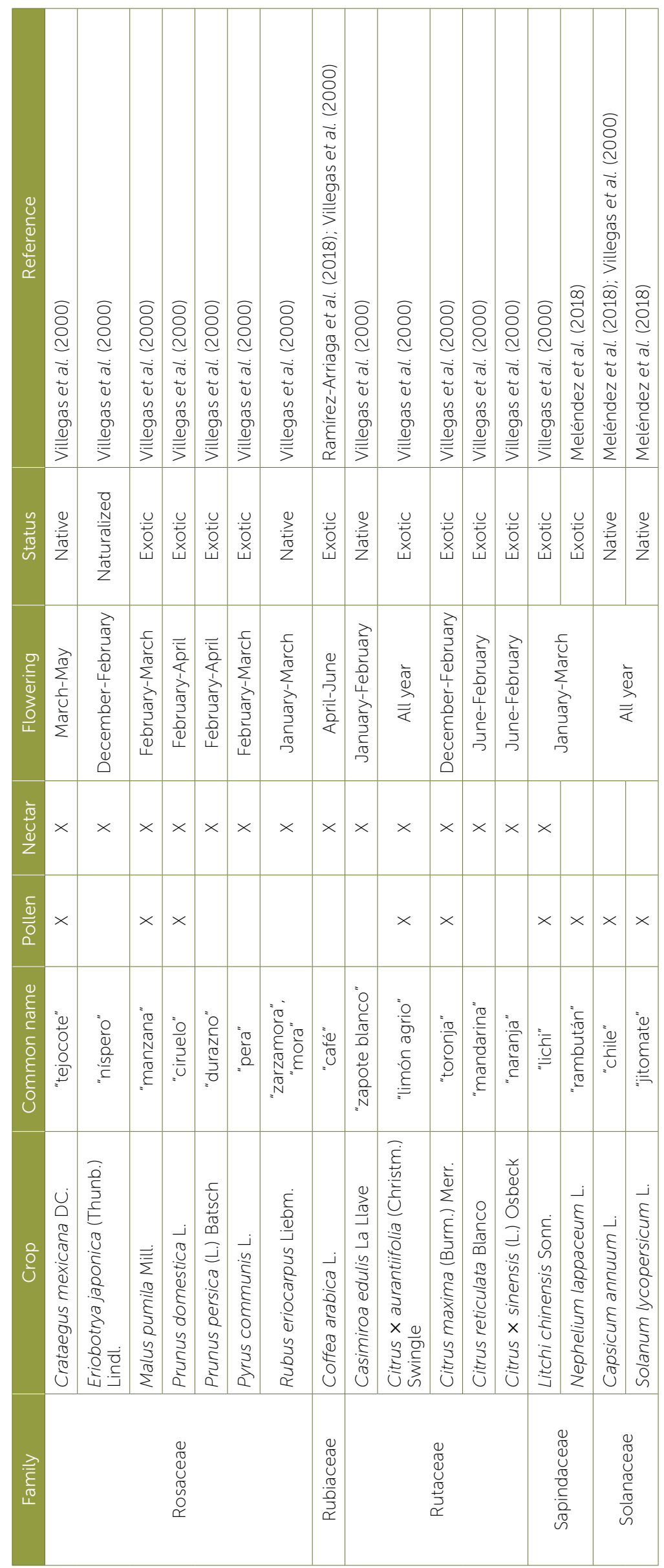

